\title{
DON QUIJOTE Y SUS FIGURAS: DE LA IMITACIÓN AL RETABLO DE MAESE PEDRO
}

\author{
Evangelina Rodriguez Cuadros \\ Universitat de València
}

\begin{abstract}
The plastic representation of don Quixote's image (likewise its philological interpretations along different ages) are not innocent; and this image seems to have been induced by the multiple meanings of the term figure ("figura"), a very often used word by Cervantes in the work (fictional novel or drama character; ridiculous, clown or fool character, the actor's role in the cast of a play or, even, materialized figures as puppets). Don Quixote builds himself through a dialectical process of dignified artistic imitation opposite to the caricatural vision of the others, a captived vision of the reality always defeated by the action (because don Quixote is mainly an acting, performing character). So, the Kinght of the "Triste Figura" faces up to alternative figures; he is urged by the artistic mimesis of models as Amadis of Gaula (when he meets Cardenio, the Knight of the "Rota Figura"), or because he rejects a debased model (the "moharracho" fool in the Death Carts episode) or because of his will to dominate the fiction as if it would be the truth (Maese Pedro's puppets). Don Quixote's image in arts evolves also from the naturalistic craft or from romantic fantasy to the abstract and analytical minimalism of his figure.
\end{abstract}

Don Quijote es el único mito de la literatura universal que se reconoce inmediatamente en un dibujo (Francisco Rico dixit). A este reconocimiento, verificado desde una interpretación emocional (no pocas veces interesadamente castiza) coadyuvan los tres elementos constructivos de la escritura cervantina: la compleja trabazón de la mímesis de la realidad, la parodia elevada al rango de la imitatio artística y la prodigiosa capacidad de improvisación teatral del héroe. Respecto al primer elemento mencionado, el tópico realista (tal vez porque invita a otorgar una total credibilidad a la imagen del protagonista) se ha impuesto ambiguamente en una tradición iconográfica (libros, grabados, pinturas) que es, sin embargo, dúctil y con una sorprendente calidad de variantes. Hasta el punto que podría decirse que la historia crítica del Quijote se escribe al mismo tiempo que se dibuja o se pinta.' En efecto, la evolución de la representación plástica y figurativa de la obra cervantina, desde el barroco al posromanticismo pasando por el propio neoclasicismo, muestra un fluctuante desmentido de la línea de realismo historicista; realismo que se esfuerza por empaparse de la concreción puntual del episodio pero que acaba casi siempre en extravagante ensoñación de aventura. No le faltaba razón a Ortega y Gasset cuando recordaba que:

la aventura quiebra como un cristal la opresora, insistente realidad. Es lo impuesto, lo impensado, lo nuevo. Cada aventura es un nuevo nacer del mundo, un proceso único. [...] Conforme va la línea de la aventura desenvolviéndose, experimentamos una tensión

\footnotetext{
'Es lo que ha llamado J. L. Giménez Frontín "unidades de información gráfica" relacionándolas con el término meme de Richard Dawkins para explicar "la contagiosa y terca propagación de algunos conceptos, imágenes, melodias o ideas". Vid. "De la pedagogia al signo", en cat. exp. Visiones del Quijote: Hogarth, Doré, Daumier, Picasso, Dali, Matta, Ponç y Saura, Barcelona, Fundació Caixa Catalunya, 2005, p. 2.
} 
emocional creciente, como si, acompañando a aquella en su trayectoria, nos sintiéramos violentamente apartados de la línea que sigue la inerte realidad. ${ }^{2}$

Pese a que su iconografia arranca, como era de esperar, de arquetipos populares del carnaval medieval y que ha sido tutelada tradicionalmente por multitud de ilustraciones posteriores - nunca inocentes, como no lo son tampoco las interpretaciones filológicas de la obra - don Quijote es el primer y gran forjador de su propia imagen, la cual modela y recrea zafándose del mapa de la realidad a través de una frenética dialéctica de autorrealización. Por eso llama la atención la más que frecuente mención de Cervantes, a lo largo de toda la obra, del término figura y el proteico significado de la misma como medio para observar, siquiera en escorzo, dicha dialéctica. Digamos, de entrada, que tal palabra posee, dentro de su polivalencia semántica, una compleja substancia teatral. ${ }^{3}$ Figura será, en el siglo XVII, el personaje interpretado por un actor en una obra de teatro (hacer la figura de). El cura de la aldea, a la hora de echar a la hoguera el Amadis de Grecia y otras secuelas del de Gaula, materializa este sentido de ente de ficción o de drama al asegurar que "quemaré con ellos al padre que me engendró, si anduviera en figura de caballero andante" $(\mathrm{I}, 6){ }^{4}$ Pero esta acepción procede del primigenio sentido de "imagen o efigie", "estatua o pintura", retrato o apariencia exterior. ${ }^{5} \mathrm{Si}$ acudimos a la materialización de esa figura del caballero, nos encontramos con que la iconografia más obsesiva del personaje literario de don Quijote es la que lo presenta dentro de su biblioteca, en la ascética soledad de la prehistoria de su aventura, motivo inmediato de parodia. En la especificidad narrativa de

\footnotetext{
${ }^{2}$ J. Ortega y Gasset, Meditaciones del Quijote, Madrid, Revista de Occidente, 1970, pp. 116-117.

${ }^{3}$ La teatralidad del Quijote ha sido objeto de numerosas reflexiones, incluidas las realizadas en pinturas o ilustraciones. Independientemente de lo que comentemos luego, bastantes representaciones de escenas quijotescas, sobre todo desde el siglo XVIII, evocan el teatro. Los interiores sugieren escenarios teatrales y los ademanes y gestos de los personajes recuerdan los dramas de la época. Charles Antoine Coypel (1694-1752), autor de una serie de pinturas e ilustraciones de las que derivaron numerosas estampas, refleja de manera excepcional, bien que volcado al estilo galante de las fiestas campestres francesas, la teatralización de escenas como las bodas de Camacho o las fiestas preparadas por los Duques en su corte. Pero es que el propio Coypel escribiría una óperaballet (Les folies de Cardénio) representada en 1720 que remite a este episodio. Por su parte Francis Hayman (1708-1776) que ilustró la traducción inglesa de la obra realizada por Tobias Smollet en 1755 muestra sensiblemente, tanto en la composición como en el fondo de sus dibujos, el completo conocimiento del mundo de la escena durante sus años como pintor de decorados teatrales. Vid. cat. exp. Imágenes del Quijote. Modelos de representación en las ediciones de los siglos XVII a XIX, Madrid, Museo Nacional del Prado, 2003. Mucho más divulgada ha sido la poderosa imaginación escénica de Gustave Doré (1832-1883), de notable influencia en la visión popular y culta del Quijote.

${ }^{4}$ De ahí que el término se emplee en la obra asimismo para designar tanto los entes de ficción (incluida la figura de Rocinante", I, 52) como las apariencias transformadas que asumen los encantadores pues "toman la figura que se les antoja" (I, 48) o la aldeana que Sancho hace pasar por Dulcinea ("que algún mal encantador [...] habrá mudado la figura...", II, 10). Y, por supuesto como apariencia o disfraz; asi en las burlas o farsas teatrales que preparan al caballero los Duques en su corte: "Si vos fuérades el diablo, como decís y como vuestra figura muestra, ya hubiérades conocido al tal caballero don Quijote de la Mancha..." (II, 34); o la figura de Merlin (en realidad el mismo Duque) confundido con la de la misma Muerte (II, 35); o la del paje de la Duquesa "que había hecho en la selva la figura encantada de Dulcinea" (II, 46). Todas estas precisiones derivan, en buena parte, del proyecto de investigación que dirijo en este momento (Léxico de la práctica escénica en el Siglo de Oro: hacia un Diccionario crítico e histórico, proyecto HUM2003-05271 subvencionado pro el Ministerio de Ciencia y Tecnologia).

${ }^{5}$ Además, naturalmente, del sentido propio de efigie o retrato: "Vio, dice la historia, el rostro mesmo, la misma figura, el mesmo aspecto, la misma fisonomía, la mesma efigie, la perspectiva mesma del bachiller Sansón Carrasco..." (II, 14).
} 
este hecho (una locura que brota de la devoradora ansiedad de la lectura de libros de caballería $)^{6}$ insisten las pinturas y los dibujos o grabados que acompañan generalmente el inicio de la obra. Entre las primeras, el Don Quijote en su estudio de Paul Bonington (ca. 1821), el Don Quijote en su biblioteca de Eugène Delacroix (1824), el saturnino Don Quijote leyendo de Honoré Daumier (ca. 1865-1867) o la irreal y flotante imagen que traslada Antonio Muñoz Degraín en Don Quijote leyendo (1919). Entre los segundos, los dibujados por José del Castillo para la edición de Ibarra de 1773-1780, por John Vanderbank en 1723, por Jean-Honoré Fragonard (ca. 1800) o por Gustavo Doré (que impone una decisiva mezcla de idealización dramática y de folclore costumbrista en la iconografia quijotesca) en 1863 [Vid. Fig. 1]. ${ }^{8}$ Además del aguafuerte de Adolf Schöedter (1843) que conforma la poderosa solidez de una figura absorta, alucinada, en trance de agitada acción inmediata en la que muchos han observado un presentimiento caricaturizado de la sombría imagen de Fausto en su estudio. ${ }^{9}$ Incluso el conocido dibujo atribuido a Francisco de Goya, muestra el determinismo estético de la lectura como inducción a la quimérica pesadilla: el personaje (que mira al espectador señalando con el dedo un enorme libro sobre la mesa) se cubre con una suerte de capirote o mitra de sospechosa semejanza con los que se imponían a los penitenciados por el Santo Oficio, y sobre él flotan monstruosos seres a lomos de un enorme y oscuro murciélago. Pero el hidalgo también muestra la tensión de la acción: la espada se apoya en el asiento, flexiona una pierna y la otra se arrodilla devota ante el conjuro de la lectura. ${ }^{10}$ Don Quijote, desde esa primera transfiguración de sí mismo, ensaya (o quizá extrae elementos a partir de los cuales improvisar) la actuación de su yo virtual. A la figura objetivada por las palabras del narrador: "Frisaba la edad de nuestro hidalgo con los cincuenta años. Era de complexión

\footnotetext{
6 "En resolución, él se enfrascó tanto en su lectura, que se pasaban las noches leyendo de claro en claro, y los dias de turbio en turbio; y así, del poco dormir y del mucho leer, se le secó el celebro de manera que vino a perder el juicio. Llenósele la fantasía de todo aquello que leía en los libros, asi de encantamentos como de pendencias, batallas, desafios, heridas, requiebros, amores, tormentas y disparates imposibles; y asentósele de tal modo en la imaginación que era verdad toda aquella máquina de aquellas soñadas invenciones que leía, que para él no había otra historia más cierta en el mundo. [...] En efeto, rematado ya su juicio, vino a dar en el más estraño pensamiento que jamás dio loco en el mundo, y fue que le pareció convenible y necesario, así para el aumento de su honra como para el servicio de la república, hacerse caballero andante..." (I, 1). Citaré siempre la obra por la ed. dirigida por F. Rico, Barcelona, Galaxia Gutemberg-Círculo de Lectores-Centro para la Edición de Clásicos Españoles, 2004.

${ }^{7}$ Véase el excelente catálogo de la exposición Una visión ensoñada del Quijote. La serie cervantina de Muñoz Degrain en la Biblioteca Nacional, Sevilla, Fundación Abengoa, 2003.

${ }^{8}$ Este grabado de Doré explicita con fuerte teatralidad el gabinete de alucinaciones y pesadillas del caballero: don Quijote, sentado en un sillón, leyendo perceptiblemente en voz alta un libro esgrime su espada y, rodeándolo, en acoso de fantástica tramoya, un amontonamiento de figuras de caballeros, doncellas amenazadas, liliputienes a lomos de ratones, amenazantes dragones y la cabezota de un gigante transformada por anamorfosis, en un cortinaje que enmarca, con perspectiva de escenario, toda la representación.

${ }^{9}$ Cfr. P. Lenagham, "'Retráteme el que quisiere pero no me maltrate.' Un recorrido por la historia de la ilustración gráfica del Quijote", en cat. exp. Imágenes del Quijote. Modelos de representación en las ediciones de los siglos XVII a XIX, citada, p. 17. Para las repercusiones del Quijote en las artes plásticas, véase J. Hartau, Don Quijote in der Kunst. Wandlurgen einer Symbolfigur, Berlin, 1987.

${ }^{10}$ Este dibujo ("Don Quijote lector"), fechado entre 1817 y 1820 , se conserva en el Museo Británico. Vid. J.L. Giménez Frontín, op. y loc. cit., p. 10.
} 
recia, seco de carnes, enjuto de rostro..." $(\mathrm{I}, 1)^{11}$ se sobrepone, como ha recordado recientemente Javier Gomá Lanzón, "el demonio del mediodía", 12 esa crisis de la personalidad que el individuo experimenta en torno a los cincuenta años cuando, harto del patrón social, anónimo e impersonal, en el que está atrapado, se exilia gozosamente a una vita nuova a partir de un programa de regeneración dictado, paradójicamente en este caso, por la tiranía fantástica de los libros de caballería tardomedievales. De ahí que, a su retrato originario, vaya adhiriéndose otra figura, objetivada esta vez por los otros, espectadores próximos que lo contemplan, como el primer ventero que advierte "aquella figura contrahecha, armada de armas tan desiguales..." (I, 2) o las doncellas "industriadas y advertidas" por los Duques en su palacio que le desnudan de las armas para observarlo

en sus estrechos gregüescos y en su jubón de camuza, seco, alto, tendido, con las quijadas que por de dentro se besaba la una con la otra: figura, que a no tener cuenta las doncellas que le servian con disimular la risa (que fue una de las precisas órdenes que sus señores les habían dado) reventaran riendo. (II, 31)

O la "doncella barbera" que deja a don Quijote con las barbas enjabonadas quedando "con la más estraña figura y más para hacer reír que se pudiera imaginar" (II, 32). Por no mencionar a las damas que en el sarao en casa de Antonio Moreno lo sacan a danzar:

Era cosa de ver la figura de don Quijote, largo, tendido, flaco, amarillo, estrecho en el vestido, desairado y, sobre todo, nonada ligero. (II, 62)

De esta delgadez amarillenta, largura de rostro y estatura desgarbada (que parecen las constantes de la etopeya quijotesca a medida que avanza la obra) ${ }^{13}$ surge una segunda

\footnotetext{
${ }^{11}$ La etopeya o retrato del propio Alonso Quijano reaparecerá, en abreviada síntesis, en las palabras de Dorotea disfrazada de Micomicona al aludir a la profecía del caballero que habría de salvarla ("que había de ser alto de cuerpo, seco de rostro", I,30) y, amplificado, en la visión que de él da el supuesto Caballero del Bosque (II, 13): "Y es un hombre alto de cuerpo, seco de rostro, estirado y avellanado de miembros, entrecano, la nariz aguileña y algo corva, de bigotes grandes, negros y caídos..." Ambas coinciden en parte con la que nos da el Caballero del Verde Gabán (una figura dignificada que se confronta con la extraña y anacrónica de don Quijote, al que contempla desde la admiratio): "La edad mostraba ser de cincuenta años; las canas, pocas, el rostro, aguileño; la vista, entre alegre y grave; finalmente, en el traje y apostura daba a entender ser hombre de buenas prendas. Lo que juzgó de don Quijote de la Mancha el de lo verde fue que semejante manera ni parecer de hombre no le había visto jamás: admiróle la longura del caballo, la grandeza de su cuerpo, la flaqueza y amarillez de su rostro, sus armas, su ademán y compostura, figura y retrato no vistos por luengos tiempos atrás en aquella tierra" (II, 16). Don Quijote es consciente del extrañamiento que su figura produce (algo que sólo aflorará en la segunda parte, cuando adquiera definitiva conciencia de ser libresco): "Esta figura que vuesa merced en mi ha visto, por ser tan nueva y tan fuera de las que comúnmente se usan, no me maravillaría yo de que le hubiese maravillado..." (II, 16). La misma admiratio producirá tal estraña figura en la mujer y en el hijo estudiante de don Diego Miranda (II, 18).

${ }^{12}$ Imitación y experiencia, Valencia, Pretextos, 2004. Vid. asimismo su artículo "El demonio del mediodia", El Pais-Babelia, 29 enero 2005 , p. 4.

${ }^{13}$ Estas constantes figurativas se mencionan entreveradas de una gestualidad a veces mesurada pero casi siempre teatral. Tal sucede en la visión que de él nos da don Fernando cuando lo ve por vez primera en la venta: “...su rostro de media legua de andadura, seco y amarillo, la desigualdad de sus armas y su mesurado continente [...] con mucha gravedad y reposo..." (I, 37). En otras ocasiones se advierte el aspecto grotesco o fiero, como el cabrero que aparece en I, 52 que ve a don Quijote "de tan mal pelaje y catadura", coincidiendo así con la mirada de los disciplinantes que aparecerán poco después; otras, en fin, se concentran en un signo de esperpéntica fantasmagoria como se le antoja a la dueña doña Rodríguez (II, 48): “... y si él quedó medroso en ver tal figura, ella quedó espantada en ver la suya, porque así como le vio tan alto y amarillo, con la colcha y con las vendas que le desfiguraban...". Antes, al regresar a su casa finalizando la primera parte de la obra, ama y sobrina han contemplado a nuestro héroe "flaco y amarillo, y tendido sobre un montón de heno y sobre un carro de bueyes..."
} 
acepción del término figura, que pierde su neutro o metafísico sentido de personaje de ficción (y su secuela de acepciones dramáticas como figura grave, figura alegórica o figura moral -cuya inclusión en la práctica escénica reivindicara el propio Cervantes ${ }^{14}$-) para convertirse en ente farsesco, ridículo o patético, que afecta entonada gravedad en sus acciones y palabras o que es, directamente, como indican los depósitos léxicos de la época, "el hombre ridículo, feo y de mala traza". La visión ofrecida por los regocijados testigos de la facha ridícula de don Quijote acaba contaminando al primer narrador supuestamente objetivo ("...se quedó toda aquella noche con la celada puesta, que era la más graciosa y extraña figura que se pudiera pensar...", I, 2). Se le llega a comparar (esta vez en la aventura del caballo Clavileño, cuando es aupado a sus ancas) con una figura de tapiz, que tiene, por supuesto, el sentido recto (una figura de estatua ecuestre romana pintada o tejida en un tapiz de Flandes, ya que el uso de los estribos no se documenta hasta el siglo VIII) pero que significa, otra vez en perspectiva farsesca, "el hombre ridículo, inhábil, o que parece que no tiene movimiento": "Y como no tenía estribos y le colgaban las piernas, no parecía sino figura de tapiz flamenco, pintada o tejida en algún romano triunfo." (II, 41). ${ }^{15}$ Se ha producido ante los ojos del lector la pirueta cruel de convertir la figura grave del hidalgo, saturnino y melancólico, absorto en su alimento de libros y lecturas en figura y su secuela implícita, carnavalizada y paródica, de figuraza, figurón, figurero, figurilla. ${ }^{16}$ Esta alquimia figurativa, que deriva en su correspondiente iconografia tradicional, es, claro está, suscitada por Cervantes; pero lo es, sobre todo, por el propio don Quijote en una emotiva autoconstrucción que, incluso desde el lado paródico y risible, tiende a la dignificación heroica, otra vez teatralizada, gestionada por su vocación autoteatral. No de otro modo

(I, 52). De modo que es evidente que Cervantes va dejando que, paulatinamente, el punto de vista del narrador objetivo se contamine de esta visión cómica y patética. Si al comienzo de la historia don Quijote es recio de carnes, su escapada caballeresca lo deja, al inicio de la segunda parte, al límite de la consunción o caquexia: "tan seco y amojamado que no parecía sino hecho de carne de momia" (II, 1); "...y venía tal el triste, que no le conociera la madre que le parió, flaco, amarillo, los ojos hundidos en los últimos camaranchones del celebro..." (II, 7).

14 "Fui el primero que representase las imaginaciones y los pensamientos escondidos del alma, sacando figuras morales al teatro, con general y gustoso aplauso de los oyentes." (En su prólogo a Ocho comedias y ocho entremeses, 1615). En el propio Quijote se testimonia el sentido de figura como personaje teatral construido desde la instancia del actor: "La más discreta figura de la comedia es la del bobo, porque no lo ha de ser el que quiere dar a entender que es simple." (II, 3); "Llegó el Interés con las figuras de su valía..." (II, 20), es decir con los personajes o danzantes de su bando, en el artificioso baile de las bodas de Camacho.

${ }^{15}$ A esta inmovilidad de las figuras de los tapices colgantes en paredes, parece referirse también Sancho cuando reprendiendo a su mujer por no creer en que el oficio de escudero puede hacerle medrar y ascender en su posición le dice: "¡No, sino estaos siempre en un ser, sin crecer ni menguar, como figura de paramento!" (II, 5)

${ }^{16}$ Figurero será, de acuerdo con el Diccionario de Autoridades (1726), "el que tiene costumbre o propensión a hacer figuradas o figurerias; figurilla, según el mismo diccionario, la figura pequeña y despreciable; Terreros y Pando en su Diccionario castellano con las voces de ciencias y artes (1786-1789) lo define como "lo pequeño y ridículo"; figurón será la figura desmedida y descompasada o el que se hace reparable por la afectación que usa (Diccionario de Autoridades) o el hombre vano, hinchado y jactancioso (según Terreros). En esta última acepción puede interpretarse el sentido de figura que confiere a la apariencia feroz de don Quijote el rico Haldudo: "El labrador, que vio sobre si aquella figura llena de armas blandiendo la lanza sobre su rostro, túvose por muerto..." $(\mathrm{I}, 4)$; experimentan el mismo temor los frailes de San Benito en la aventura del vizcaino: "Detuvieron los frailes las riendas, y quedaron admirados asi de la figura de don Quijote..." (I, 8). El sentido de figura festiva de la locura, a modo bufonesco, aparece cuando los mercaderes, ignorando el "gentil continente y denuedo" y el "ademán arrogante" con el que el caballero se ha investido tan teatralmente, toman nota de "la extraña figura del que las decía; y por la figura y por las razones luego echaron de ver la locura de su dueño..." $(I, 4)$. 
deben entenderse los dos autobautismos fundacionales de su materialización como figura de caballero andante. El primero, en el bellísimo capítulo inicial (que habría que considerar, por tantos motivos, el gran guión esquemático del plan de la obra entera). Abandonando la borrosa y lábil identidad de Alonso Quijano (o Quijada o Quesada), en una prodigiosa operación de improvisación (a partir de la premeditada gestión de su fantasía) decide llamarse don Quijote. Es decir, asume la identidad nominal que le proporciona una parte del atuendo o vestuario de la figura del caballero andante, puesto que quijote es la parte de la armadura que cubre el muslo, identidad que él eleva de inmediato a un patronímico diginificador y literaturesco -de ahí la sonoridad evocativa de, por ejemplo, Lanzarote-, pero con la malévola retranca del sufijo-ote, presente en todo lo jocoso o grotesco. A ello añade, como cabía esperar de quien se está constituyendo en genial actor de la imitación artística o literaria, el "de la Mancha" (como Amadís se hizo llamar "de Gaula"), "con que a su parecer declaraba muy al vivo su linaje y patria" (I, 1). El segundo, en perfecta colaboración con Sancho, tiene lugar en la nocturnal aventura del cuerpo muerto con el que topan y contra el que arremete, sin piedad, el caballero. Puesto en fuga el séquito, el escudero grita orgulloso que quien en tal trance los ha puesto "es el famoso caballero don Quijote de la Mancha, que por otro nombre se llama Caballero de la Triste Figura" (I, 19). Las razones que da son plásticamente rotundas (otro signo escrito que determina la iconografia posterior):

Porque le he estado mirando un rato a la luz de aquella hacha que lleva aquel malandante, y verdaderamente tiene vuestra merced la más mala figura, de poco acá, que jamás he visto; $y$ débelo haber causado, o ya el cansancio deste combate, o ya la falta de muelas y dientes. (I, 19)

Don Quijote, hasta ese momento sometido a la anonimia del caballero novicio, ${ }^{17}$ ve abierto el telón del teatro de su autorrealización, un plan perfectamente previsto por el caballero desde su primera salida pero cuya ejecución traslada a los otros, los que, en el futuro, habrán de escribir su historia:

Dichosa edad y siglo dichoso aquel adonde saldrán a luz las famosas hazañas mías, dignas de entallarse en bronces, esculpirse en mármoles y pintarse en tablas, para memoria en lo futuro. (I, 2)

Pero la ocurrencia literal de Sancho (evocar la figura maltrecha, ridícula, de talle desgarbado, como en otros momentos contempla a su amo derrotado y escarnecido "de muy mal arte" -tal sucede tras la batalla con los ejércitos de ovejas en I, 18-) es trasladada por su don Quijote al plano de la imitatio. Y así, el caballero decide adoptar este apelativo por razones heroicas y dignificadoras; si los caballeros a los que conoció en los poblados estantes de su biblioteca (allí donde fue pintado o dibujado como anciano decrépito con gorro de dormir o poseído por la melancolia, su mano en la mejilla, clavada la mirada en un libro abierto y la pierna sobre un rimero de libracos) podian hacerse llamar "el de la Ardiente Espada", el del "Unicornio" o el "del Ave Fénix", su escudero le ha dado el pie para su nueva identidad:

\footnotetext{
${ }^{17}$ Cuando, en su primera salida, recuerda que aún no ha sido armado caballero, don Quijote, con su férrea éticolibresca se impone que "habia de llevar armas blancas, como novel caballero, sin empresa en el escudo, hasta que por su esfuerzo la ganase" (I, 2). Es decir sin empresa pintada, sin dibujo simbólico ni lema.
} 
Digo que el sabio ya dicho te habrá puesto en la lengua y en el pensamiento ahora que me llamases el Caballero de la Triste Figura, como pienso llamarme desde hoy en adelante; y para que mejor me cuadre tal nombre, determino de hacer pintar, cuando haya lugar, en mi escudo una muy triste figura. (I, 19)

Don Quijote, soslayando la competencia naturalista o realista del símil que le ha proporcionado Sancho, ${ }^{18}$ la traslada al plano simbólico de su autoconstitución artística. Él determina, quiere, hace, actúa: el querer o no querer (el no querer siquiera recordar el lugar de la Mancha en donde todo comienza, con lo que convierte el déficit de memoria en un acto de libertad) prevalece sobre el deber o no deber de lo géneros o del guión realista escrito previamente. Don Quijote se convierte en lo que es, desde luego, porque habla como habla y porque piensa como piensa, pero, sobre todo, porque actúa como actúa. Pero si todos los actores (o los llamados entonces farsantes) pueden interpretar, mal que bien, un personaje, sólo don Quijote puede desdoblarse, con precisión conceptual e iconográfica, desde su figura en otra figura. Puede ser e interpretar la figura del modelo leído. En definitiva, puede convertir su aventura no en un ramplón relato realista sino en una obra de arte (en todo su polivalente sentido). "Yo sé quien soy — dirá-, y sé que puedo ser, no sólo los que he dicho, sino todos los pares de Francia, y aun todos los nueve de la Fama..." (I, 5). Andrenio, el protagonista del Criticón de Gracián, afirmará, por el contrario: "Yo ni sé quién soy ni quién me ha dado el ser ni para qué me lo dio..." (Crisi 1$)$. Puede retarse a cualquier sesudo especialista a que encuentre una representación iconográfica, dignificada o antiheroica, de tan triste (esta sí) figura gracianesca. Por el contrario, en don Quijote se materializa un cuidadoso plan de autorrealización a partir de la imitatio, plan que verbaliza en todos sus componentes y modelos. Véase su reacción cuando contempla la llegada de los mercaderes murcianos con su séquito de criados, caballerías y quitasoles:

Apenas los divisó don Quijote, cuando se imaginó ser cosa de nueva aventura; y, por imitar en todo cuanto a él le parecia posible los pasos que habia leido en sus libros, le pareció venir alli de molde uno que pensaba hacer. $(I, 4)$

El momento culminante de este hacer de su figura una lujosa imitación artística, será la célebre penitencia en Sierra Morena. Al adentrarse en ella "se le alegró el corazón, pareciéndole aquellos lugares acomodados para las aventuras que buscaba. Reducíansele a la memoria los maravillosos acontecimientos que en semejantes soledades y asperezas

\footnotetext{
18 "No hay para qué gastar tiempo y dineros en hacer esa figura - dijo Sancho-, sino lo que se ha de hacer es que vuestra merced descubra la suya y dé rostro a los que le miraren, que sin más ni más, y sin otra imagen ni escudo, le llamarán el de la Triste Figura; y créame que le digo la verdad, porque le prometo a vuestra merced, señor (y esto sea dicho en burlas), que le hace tan mala cara el hambre y la falta de las muelas, que, como ya tengo dicho, se podrá muy bien escusar la triste pintura" $(\mathrm{I}, 19)$. Como puede comprobarse Sancho enlaza el sentido de figura como efigie o retrato inmediato con el de figura lastimeramente burlesca. Con la misma ironía le replica a su amo tras narrarle éste, en rocambolesca idealización de futuro, las aventuras y parabienes que les aguardan en su peripecia: "Todo al pie de la letra ha de suceder por vuestra merced llamándose el Caballero de la Triste Figura" (I, 21); o cuando le comenta despechado tras ver volatilizarse el servicio de don Quijote a la supuesta princesa Micomicona: "Bien puede vuestra merced, señor Triste Figura, dormir todo lo que quisiere, sin cuidar de matar a ningún gigante ni de volver a la princesa a su reino..." (I, 37). Todos los personajes participan constantemente de estas transformaciones de la imagen quijotesca. Incluso el bandolero Roque Guinart que parece ser el único, junto a Sancho, que pondera la dignidad de la tristeza que asume como lema el caballero: "Admiróle ver lanza arrimada al árbol, escudo en el suelo, y a don Quijote armado y pensativo, con la más triste y melancólica figura que pudiera formar la misma tristeza." (II, 60)
} 
habían sucedido a caballeros andantes" (I, 23). Don Quijote halla así un espacio o decorado teatral adecuados. Falta el atrezzo correspondiente. Poco antes él y Sancho han encontrado una maleta abandonada y, dentro, un librillo de memorias en el que el caballero fija su atención para encontrar, de inmediato, el borrador de un soneto y el de la carta de un amante despechado. Ya sólo necesita que alguien le de el pie para otra elevación heroica de su figura. Ese alguien (que, sólo después, conoceremos como Cardenio) aparece

por cima de una montañuela [...] saltando de risco en risco y de mata en mata con estraña ligereza. Figurósele que iba desnudo, de barba negra y espesa, los cabellos muchos y rabultados, los pies descalzos y las piernas sin cosa alguna; los muslos cubrían unos calzones, al parecer de terciopelo leonado, mas tan hechos pedazos, que por muchas partes se le descubrian las carnes... (I, 23)

El Caballero de la Triste Figura ha encontrado al "roto de la Mala Figura" (I, 23). Dos figuras frente a frente. ${ }^{19}$ El "Roto" - "astroso Caballero de la Sierra" u hombre salvaje recuperado de la mitología medieval-cuenta su mal de amores al de la Triste Figura y, en efecto, le da el pie justo en el momento en que rememora como su amada le pidió un libro llamado Amadis de Gaula. Salta la chispa: el roto Cardenio menosprecia la obra y don Quijote se encalabrina, mientras que el salvaje enamorado vuelve a adentrarse en el bosque. Tal chispa cristaliza la situación teatral de la figura que, en un acto de suprema voluntad, había creado desde sí mismo el hidalgo. En Cardenio ha visto un sospechoso contrafacta de su propia triste figura: estímulo o improvisación que sutura con el referente de la imitación, del deber ser aristotélico. Su modelo es, precisamente, Amadís: "Hallo yo, Sancho amigo, que el caballero andante que más le imitare, estará más cerca de alcanzar la perfección de la caballería" (I, 25). No es casualidad que si Giorgio Vasari en sus Vidas de artistas de 1550 había cifrado la perfección artística en imitar los originales de las cosas que se suponen realizadas por los grandes maestros, Cervantes ponga en boca del hidalgo:

que cuando algún pintor quiere salir famoso en su arte procura imitar los originales de los más únicos pintores que sabe, y esta mesma regla corre por todos los oficios o ejercicios de cuenta que sirven para adorno de las repúblicas. (I, 25)

Nunca ningún personaje o figura de ficción fue tan radical e insensatamente moderno y nunca la modernidad logra encarnarse tanto en un individuo históricamente renacentista. El Renacimiento, en efecto, fue la imitación hecha época. Y la imitación, en sentido estricto, es siempre idealista porque presupone un modelo normativo y ejemplar. Don Quijote, para "echar el sello a todo aquello que puede hacer perfecto y famoso a un andante caballero" (I, 25 ) imitará a Amadís que, al sentirse desdeñado por Oriana (Amadís de Gaula, II, 48-52), hizo penitencia en la Peña Pobre bajo el nombre de Beltenebros. ${ }^{20}$ Es verdad que, tras la

\footnotetext{
19 'El otro, a quien podemos llamar 'el Roto de la Mala Figura' (como a don Quijote el de la Triste), después de haberse dejado abrazar, le apartó un poco de sí y, puestas sus manos en los hombros de don Quijote, le estuvo mirando, como que queria ver si le conocia, no menos admirado quizá de ver la figura, talle y armas de don Quijote que don Quijote lo estaba de verle a él." (I, 23)

${ }^{20}$ Una imitatio que se preludia en el soneto del mismísimo Amadís de Gaula en los preliminares de la primera parte de la obra: "Tú, que imitaste la llorosa vida / que tuve, ausente y desdeñado, sobre / el gran ribazo de la Peña Pobre..." El tema es, además, introducido por el propio Cervantes ya en el capítulo 15 de la primera parte cuando don Quijote recuerda a Sancho los sinsabores y austeridad de la vida caballeresca que les lleva a dormir en páramos y desiertos: "...que ha habido caballero que se ha estado sobre una peña, al sol y a la sombra y a las inclemencias del cielo, dos años, sin que lo supiese su señora. Y uno déstos fue Amadís, cuando, llamándose
} 
chispa del enfrentamiento con la mala figura de Cardenio, don Quijote estará tentado de asumir el modelo de otra figura e "imitar al valiente don Roldán" [Orlando furioso], traicionado por Angélica a la que ve en brazos de Medoro, "de cuya pesadumbre se volvió loco, y arrancó los árboles, enturbió las aguas de las claras fuentes, mató pastores, destruyó ganados, abrasó chozas..." (I, 25). Pero opta por hacer

el bosquejo como mejor pudiere en las que me pareciese ser más esenciales. Y podrá ser que viniese a contentarme con solo la imitación de Amadís, que sin hacer locuras de daño, sino de lloros y sentimientos, alcanzó tanta fama como el que más. (I, 25)

Muchos leerán (o pintarán o dibujarán) esta escena vinculada a la grotesca hoguera de la locura: ahí tenemos esas ilustraciones de don Quijote, otra vez figura patética, en carnes y en pañales, dando, ante el aterrado Sancho, zapatetas al aire con los pies y tumbos de cabeza abajo. Pero si pone en práctica ante el escudero este bosquejo gestual de su enajenada penitencia ("ahora me falta rasgar vestiduras, esparcir las armas y darme de calabazadas por estas peñas, con otras cosas deste jaez, que te han de admirar"), aún en peligro de quedar desfigurado de la dieta a base de hierbas $(\mathrm{I}, 26)$, es por alcanzar el punto de imitatio perfecta de su modelo, por interpretar de veras a su personaje, tal como advierte a Sancho:

Quiérote hacer sabidor de que todas estas cosas que hago no son de burlas, sino muy de veras, porque de otra manera sería contravenir a las órdenes de caballería, que nos mandan que no digamos mentira alguna, pena de relasos, y el hacer una cosa por la otra lo mesmo es que mentir. Ansí que mis calabazadas han de ser verdaderas, firmes y valederas, sin que lleven nada del sofístico ni del fantástico. $(\mathrm{I}, 25)^{21}$

Pero el escenario es mucho más sobrio, contenido, digno. Don Quijote elige una montaña "que casi como peñón tajado estaba sola entre otras muchas que la rodeaban. Corría por su falda un manso arroyuelo, y hacíase por toda su redondez un prado tan verde y vicioso, que daba contento a los ojos que le miraban. Había por allí muchos árboles silvestres y algunas plantas y flores, que hacían el lugar apacible" (I, 25). Allí, en soledad, en medio de una escenografía de boscarescha, y aplicando el venturoso presentimiento del como si stanislavskiano, opta por la levantar en vilo su vida al nivel de la perfecta imitación artística de Amadís, recurriendo, como disciplinado actor, a la improvisación y a su propia memoria: "Viva la memoria de Amadís, y sea imitado de don Quijote de la Mancha en todo lo que pudiere [...] Venid a mi memoria, cosas de Amadís, y enseñadme por dónde tengo que comenzar a imitaros..." $(\mathrm{I}, 25)$

Esa mayor y más emotiva dignidad será la que muestre el grabado de Francis Engleheart (a partir del dibujo de Robert Smirke) en la edición inglesa de la obra de 1818 [Vid. Fig. 2]. En ella no vemos una avejentada figura farsesca sino un caballero maduro (mimetizado, para qué negarlo, con la prosapia retórica del gesto de un landlord inglés) que, dispersadas sus armas, se aúpa sobre una peña en una inestable gravedad

Beltenebros, se alojó en la Peña Pobre, no sé si ocho años u ocho meses, que no estoy muy bien en la cuenta: basta que él estuvo alli haciendo penitencia, por no sé qué sinsabor que le hizo la señora Oriana".

${ }^{21}$ Igual de patética pero con idéntico empeño verista es la facha grotesca del hidalgo en su sonámbula pelea con los cueros de vino en la venta donde se le describe en camisa, que apenas le cubre los muslos "y por detrás seis dedos menos; las piernas eran muy largas y flacas, llenas de vello y nonada limpias" y cubierto con un ridiculo gorro de dormir colorado (I, 35). 
autosuficiente. Siempre la imitación, o, desde otro punto de vista, la libérrima improvisación a partir de los elementos que le dispensa un escenario y quienes, accidentalmente, lo pueblan. Sea, por ejemplo, el rememorado episodio del yelmo de Mambrino que don Quijote cree ver en la bacía de azófar de un pobre barbero acomodado sobre un asno. La limpia bacía relumbra a los rayos del sol que aparece tras un aguacero. Bastan estos mínimos elementos y "ésta fue la ocasión que a don Quijote le pareció caballo rucio rodado y caballero y yelmo de oro, que todas las cosas que veía con mucha facilidad las acomodaba a sus desvariadas caballerías..." $(I, 21)$. Por primera vez en las letras occidentales Cervantes, en el Quijote, explora asi la posibilidad de que la voluntad de un hombre se convierta en su propia conciencia, trasvasando una ética (ser un hombre libre) a una estética (ser un hombre autónomo) y fatigando hasta el extremo el camino, de doble dirección, entre ambas opciones. Porque don Quijote siempre tendrá presente el gesto total de imitación (ética y figurativa) respecto al modelo. No en vano, ya en la segunda parte, para reafirmarse en la verdad incontestable de ese modelo, evoca con emotiva precisión la etopeya física y moral (pero también plástica) del héroe:

La cual verdad es tan cierta, que estoy por decir que con mis propios ojos vi a Amadís de Gaula, que era un hombre alto de cuerpo, blanco de rostro, bien puesto de barba, aunque negra, de vista entre blanda y rigurosa, corto de razones, tardo en airarse y presto en deponer la ira; y del modo que he delineado a Amadís, pudiera, a mi parecer, pintar y describir todos cuantos caballeros andantes andan en las historias en el orbe, que por la aprehensión que tengo de que fueron como sus historias cuentan, y por las hazañas que hicieron y condiciones que tuvieron, se pueden sacar por buena fisonomía sus facciones, sus colores y sus estaturas..." (II, 1)

A partir de ese momento culminante, la figura de don Quijote, dentro de su oscilante vacilación (personaje de ficción, personaje autoconstruido como figura artística y teatralmente elevada, fantoche ridículo) no admitirá la competencia de otras figuras. Porque todavía las hay. La demencia de don Quijote exige una cura de la misma etiología: la medicina de un regreso a la realidad coherente con el guión teatral por él mismo diseñado. Tal es el recurso empleado por los bienintencionados amigos que recurren a la estrategia actoral de convertirse en figuras para secuestrar a don Quijote y devolverle a la aldea. El caballero responde como espectador alucinado ante el espectáculo de figuras contrahechas (Dorotea será la única que viste dignamente su papel de doncella menesterosa):

Por orden y parecer del cura, se cubrieron los rostros y se disfrazaron, quién de una manera y quién de otra, de modo que a don Quijote le pareciese ser otra gente de la que en aquel castillo había visto. [...] De modo que cuando él despertó con sobresalto no pudo menearse ni hacer otra cosa más que admirarse y suspenderse de ver delante de sí tan estraños visajes; y luego dio en la cuenta de lo que su continua y desvariada imaginación le representaba, y se creyó que todas aquellas figuras eran fantasmas de aquel encantado castillo... (I, 46)

Dos episodios de la segunda parte de la obra, objeto frecuente asimismo de la iconografia quijotesca, culminan este proceso. En uno de ellos el caballero da de bruces con un hecho teatral real, cuando una carreta "salió a través del camino cargada de los más diversos y extraños personajes y figuras que pudieron imaginarse" (II, 11). En ella viaja la compañía de la legua de Angulo el Malo que se dispone a poner en escena un auto con todos sus integrantes, vestidos tal cual exigen la pieza y las prisas por llegar de una villa a otra para la representación acordada. Una carreta descubierta, "sin toldo ni zarzo" (es decir, 
sin cañizo o armazón, probablemente la propia plataforma que sirve de escenario) transporta a actores, farsantes o recitantes o, por mejor decir, al Diablo, a la Muerte, a un Ángel con alas pintadas, a un Emperador con su corona de oropel, a un Cupido con carcaj y flechas, a una Reina y a un caballero armado de punto en blanco, sin morrión ni celada pero con un sombrero de plumas. ${ }^{22}$ Don Quijote se dispone a entrar en escena, aunque ésta escape al género habitual en que mejor se desenvuelve como actor (a saber, el inagotable repertorio de la caballería). Las palabras de la figura del diablo-carretero que, rompiendo la ficción, le aclaran que en realidad se enfrenta a una compañia de cómicos, detienen al de la Triste Figura. El teatro oficial, materializado, no le interesa sino como cultura asimilada ("desde mochacho fui aficionado a la carátula, y en mi mocedad se me iban los ojos tras la farándula") o como constatación lúcida de "tocar apariencias y desengaños". En esa particular representación de las Danzas de la Muerte no entra don Quijote sino por provocación o estímulo negativo de brusca improvisación. Porque tras las figuras homologables a su propia figura (papeles o partes concretas de una concreta acción) aparece

uno de la compañía que venía vestido de bojiganga, con muchos cascabeles, y en la punta de un palo traía tres vejigas de vaca hinchadas; el cual moharracho, llegándose a don Quijote, comenzó a esgrimir el palo y a sacudir el suelo con las vejigas y a dar grandes saltos, sonando los cascabeles... (II, 11)

El espejismo teatral se materializa de manera sangrante: un loco bufón se enfrenta a un hildalgo loco. Una mala figura, torpe y grotesca, entra en competencia con una Triste Figura y ésta no puede soportar el espejo que se le pone delante. Don Quijote, que había expresado al inicio del capítulo su desazón por la mala burla de los encantadores "volviendo a su señora Dulcinea en la mala figura de una aldeana" (II, 10), cae de su montura. El bufón bailador espolea al rucio de Sancho e intenta huir pero también es apeado. En una imitatio de rango esperpéntico el loco-bufón-moharracho remeda sarcásticamente la derrota del caballero y la compañía de Angulo el Malo se dispone a apedrearle. Páginas después el hidalgo recordará aquello de que "ninguna comparación hay que más al vivo nos represente lo que somos y lo que habemos de ser como la comedia y los comediantes" (II, 12). Un polvoriento camino de la Mancha se ha convertido en el gran teatro del mundo.

El otro episodio protagonizado por figuras es el que sucede con el reencuentro de Ginés de Pasamonte, a la sazón disfrazado de titiritero, y con un atuendo no menos extraño (parche verde en el ojo, traje de camuza y un mono subido al hombro). Don Quijote, ya experto catador de figuras, sabe que se enfrenta a farsistas de embelecos. Del pintoresco ñaque adivinador del pasado y presente (que no de lo que ha de acontecer), dice el caballero

\footnotetext{
${ }^{22}$ La iconografia más conocida del episodio es el grabado que el pintor flamenco Frederik Bouttas (ca. 1610-1676) realiza para la edición de Bruselas de 1662 [Fig. 3], en la que por primera vez en una impresión en castellano se incluian 34 "estampas muy donosas", la mayoría copiadas de la edición holandesa de 1657. Aunque, dentro de una tonalidad de humor tosco, se ha reprochado a estos grabados su desacierto para reproducir de manera exacta el ambiente español, optando por el mundo de la representación de Vermeer, Brueghel y el norte de Europa, acierta en lo principal; es decir, visualizar en tres planos superpuestos los tres nudos de la acción del episodio: la carreta con los actores en los que es perceptible su vestuario emblemático, el instante en que don Quijote cae de Rocinante ante la presencia del moharracho (éste representado de espaldas, sin responder en absoluto a la expresiva descripción de Cervantes) y, en primer plano, un asustado Sancho sobre su pollino.
} 
que "este mono no es astrólogo, ni su amo ni él saben alzar estas figuras que llaman judiciarias, que tanto ahora se usan en España, que no hay mujercilla, ni paje, ni zapatero de viejo que no presuma de alzar una figura, como si fuera una sota de naipes del suelo" (II, 25), jugando a la anfibología de alzar las cartas de figura de los naipes (sota, caballo, rey) y de alzar la figura o disponer la carta astrológica con las distintas posiciones del zodíaco. Pero son otras las figuras que se van a levantar. El pícaro Ginés, haciéndose llamar Maese Pedro, se dispone a representar la historia de Gaiferos y Melisendra a través de un retablo de figuras, esta vez en su acepción primigenia de estatuas que representan a persona o cosa viviente, es decir, figurillas, figuras de pasta. ${ }^{23} \mathrm{El}$ concepto de retablo que aparece en este caso ya ha adquirido un sentido más complejo que el original que ofrece Sebastián de Covarrubias en su Tesoro de la lengua castellana, a saber, "la tabla en que está pintada alguna historia de devoción", y que, trasladada al artilugio de figurillas de pasta o titeres, "representa una historia sagrada, y de alli les dieron el nombre de retablos." Esta acepción peyorativa de una invención guiñolesca atribuida sobre todo a italianos (no por casualidad, Maese Pedro es presentado por el ventero bajo el talante de "hombre galante, como dicen en Italia, y bon compaño"), que aún empapa los dicterios que dirige el licenciado Vidriera a los titiriteros, ${ }^{24}$ se amplía en el episodio quijotesco que referimos al conjunto de figuras corpóreas que representan algún suceso (Lat. Tabula variis imaginibus depicta"). Las nuevas figuras con las que se enfrenta don Quijote son títeres en su sentido más pleno, ${ }^{25} \mathrm{y}$ Cervantes despliega, como suele hacer, su gran sentido de la precisión léxica respecto a la nomenclatura teatral. Maese Pedro es titerero, variante de titiritero o titerista: "Este es un famoso titerero, que ha muchos días que anda por esta Mancha de Aragón enseñando un

\footnotetext{
23 "Esta figura que aquí aparece a caballo, cubierta con una capa gascona, es la mesma de don Gaiferos..." (II, 26). Compárese con las intervenciones de Chanfalla o la de Chirinos en El Retablo de las Maravillas: "...por aquella parte asoma la figura del valentísimo Sansón, abrazado a las columnas del templo...", o de los propios asustados campesinos, en la misma obra: "Señor Autor, si puede, que no salgan figuras que nos alboroten" (edición de Entremeses de N. Spadaccini, Madrid, Cátedra, 1988, pp. 227-228).

24 "De los titereros decía mil males: decía que era gente vagamunda y que trataba con indecencia de las cosas divinas, porque con las figuras que mostraban en sus retablos volvían la devoción en risa, y que les acontecía envasar en un costal todas o las más figuras del Testamento Viejo y Nuevo y sentarse sobre él a comer y beber en los bodegones y tabernas: en resolución, decía que se maravillaba de cómo quien podía no les ponía perpetuo silencio en sus retablos, o los desterraba del reino." (Novelas Ejemplares, ed. de J.B. Avalle Arce, Madrid, Castalia, 1982, vol. II, pp. 134-135)

${ }^{25}$ Titeres viene definido por Covarrubias como "ciertas figurillas que suelen traer extranjeros en unos retablos, que mostrando tan solamente el cuerpo dellos, los gobiernan como si ellos mesmos se moviesen, y los maestros que están dentro, detrás de un repostero y del castillo que tienen de madera, están silbando con unos pitos, que parece hablar las mesmas figuras; y el intérprete que está acá fuera declara lo que quieren decir, y porque el pito suena ti ti, se llaman títeres." El retablo que representan al alimón Maese Pedro y el muchacho declarador o intérprete no ha llegado al extremo de sofisticación de las figuras autómatas que señala asimismo: "Hay otra manera de títeres, que con ciertas ruedas como de reloj, tirándole las cuerdas, van haciendo sobre una mesa ciertos movimientos, que parecen personas animadas, y el maestro los trae tan ajustados que en llegando al borde de la mesa dan la vuelta, caminando hasta el lugar de donde salieron. Algunos van tañendo un laúd, moviendo la cabeça y meneando las niñas de los ojos; y todo esto se haze con las ruedas y las cuerdas. En nuestro tiempo lo hemos visto, y fue invención de Juanelo, gran matemático y segundo Arquimedes..." El Diccionario de Autoridades define: "Figurilla de pasta u otra materia, vestida y adornada, que se mueve con alguna cuerda, o artificio, con acciones risibles, o representando algún papel con las acciones, el cual explica la persona que le gobierna". Mientras que, ya casi a finales del XVIII, Terreros introduce una clara visión más despectiva y farsesca: "Mono, monillo. Nombre que se da a algunas figurillas que se mueven con algunos muelles o cuerdas, de modo que parecen vivas, $\mathrm{y}$ sirven a los charlatanes para sus juegos y habilidades."
} 
retablo de Melisendra" (II, 25); tras este disfraz anda Ginés de Pasamonte "...acomodándose al oficio de titerero; que esto y el jugar de manos lo sabía hacer por estremo..." (II, 27). El retablo de títeres es, para Cervantes y buena parte de sus contemporáneos, teatro encanallado. Si Alonso Jerónimo Salas Barbadillo en su entremés El caballero bailarín se refiere a la baja estofa de un actor que reduce su técnica a este tipo de figuras, ${ }^{26}$ Luis de Belmonte insiste en La maestra de gracias en el carácter farsesco y poco noble del espectáculo. ${ }^{27} \mathrm{Y}$ el propio Cervantes pone en boca de Chanfalla y Chirinos en El Retablo de las Maravillas que con la oferta de su espectáculo busca remediar a "los cofrades de los hospitales, porque no hay autor de comedias en ella, y perecen los hospitales". 28 Un teatro de impostura parece estar sustituyendo, según Cervantes, la creación teatral al modo de distanciamiento prebrechtiano que, sin perjuicio de su propia evolución como autor dramático, ha predicado en la teoría expuesta por el canónigo de Toledo en el capítulo 48 de la primera parte de la obra.

Espectáculo de la legua, circense, que mezcla la fanfarria tramoyística (se subraya el ruido de "cantidad de atabales y trompetas" y el "dispararse mucha artillería" que suena tras el retablo y las apariencias de las torres de la Aljafería de Zaragoza y el balcón de la dama) y el arte de los títeres con la habilidades adivinatorias del mono, el retablo es otro violento tropezón del Caballero de la Triste Figura con el juego especular de apariencias y realidad de otras figuras por la que se sentirá irremisiblemente aludido:

... y vinieron donde ya estaba el retablo puesto y descubierto, lleno por todas partes de candelillas de cera encendidas que le hacían vistoso y resplandeciente. En llegando se metió Maese Pedro dentro dél, que era el que habia de manejar las figuras del artificio, y fuera se puso un muchacho, criado del maese Pedro, para servir de intérprete y declarador de los misterios del tal retablo: tenía una varilla en la mano, con que señalaba las figuras que salían. (II, 25)

De igual modo que los truhanes declaradores del entremés El Retablo de las Maravillas (Chanfalla y Chirinos) despiertan con su verbosidad tramoyística la colaboración del grupo de villanos ricos en la representación del mundinuevo ideado por el sabio Tontonello, con sus ribetes de magia astrológica y brujeril, ${ }^{29}$ el relato del intérprete o declarador (poderosa

\footnotetext{
26 "No soy cantor de máscara ni titere; / que canto sin visajes ni meneos, / y esta en quien canta es propiedad muy buena, / sereno el rostro y en la voz Sirena." (E. Cotarelo y Mori, Colección de entremeses, loas, bailes, jácaras y mojigangas desde fines del siglo XVI a mediados del siglo XVIII, Madrid, Nueva Biblioteca de Autores Españoles, 1911, p. 293').

27 "Cesacio de comedias y entremeses, / que la vida les quitas, / y titeres muñecos resucitas, / poniendo este tablado, / como va de lo vivo a lo pintado" (Ramillete de entremeses y bailes nuevamente recogidos de los antiguos poetas de España. Siglo XVII, ed. de H. E. Bergman, Madrid, Castalia, 1970, vv. 72-76).

${ }^{28}$ Vid. ed. citada, p. 219.

${ }^{29}$ Del mismo modo que las habilidades de predicción del mono hacen sospechar a don Quijote que "su amo debe de tener hecho pacto tácito o espreso con el demonio." (II, 25), Chanfalla en El Retablo de las Maravillas se hace llamar asimismo Montiel (Montiela en El coloquio de los perros era la bruja madre de uno de los canes hechizados). El retablo representado (espectáculo de títeres llamado asimismo mundimuevo) basa la magia de sus condiciones de invisibilidad en haberlo compuesto el sabio italiano Tontonello "debajo de tales paralelos, rumbos, astros y estrellas, con tales puntos, caracteres y observaciones, que ninguno pueda ver las cosas que en él se muestran que tenga alguna raza de confeso, o no sea habido y procreado de sus padres de legítimo matrimonio; y el que fuere castigado destas dos tan usadas enfermedades, despidase de ver las cosas, jamás vistas ni oídas, de mi retablo." Las palabras de Chanfalla que abren la supuesta representación no dejan margen de duda respecto a su condición de conjuro demoníaco: "Te conjuro, apremio y mando..." (vid. ed. citada, p. 220).
} 
evocación de la oralidad como viva disposición kinésica o teatralizante del relato), ${ }^{30}$ casi más que la propia acción guiñolesca - pues Ginés de Pasamonte se limita a mover las figuras y no a imitar sus voces- embelesan a don Quijote, quien se queja no de la detallada descripción volcada a la teatralidad de la "verdadera historia [...] sacada al pie de la letra de las corónicas francesas y de los romances españoles", sino de los avatares extradramáticos. Sólo cuando el declarador empieza a realizar disquisiciones sobre el diferente sistema jurídico de los moros bramará el caballero en una perfecta declaración de principios sobre la unidad de acción: "Niño, niño - dijo en voz alta a esta sazón don Quijote-, seguid vuestra historia en línea recta, y no os metáis en las curvas o transversales..." (II, 26). ${ }^{31}$ Reclama la rectitud sin prolijidad y reclama (irónica demanda a alguien revestido del peso de su paranoia caballeresca) la propiedad y verosimilitud. Cuando el joven trujamán describe la ciudad por la que huyen los amantes envuelta en "el son de las campanas que en todas las torres de las mezquitas suenan", don Quijote denuncia el disparate:

En esto de las campanas anda muy impropio maese Pedro, porque entre moros no se usan campanas, sino atabales y un género de dulzainas que parecen nuestras chirimías... (II, 26)

Maese Pedro, justificando el dislate en la representación de ordinario de "mil comedias llenas de mil impropiedades y disparates" que "corren felicísimamente su carrera y se escuchan no sólo con aplauso, sino con admiración y todo", termina por mostrar el aspecto venal de su oficio: "Prosigue muchacho, y deja decir, que como yo llene mi talego, siquiera represente más impropiedades que tiene átomos el sol." Se diría que Cervantes reescribe en clave de títeres la ponderada visión sobre el teatro convertido en mercaduría vendible que denuncia el Canónico de Toledo $(\mathrm{I}, 48)$. Como ha señalado acertadamente Jesús G. Maestro $^{32}$ el episodio expone con pulcritud las formas épicas que Bertold Brecht propondría para su teatro: un escenario (retablo con ingenuas apariencias de urbe medieval) que narra en sí mismo los hechos; un actor - desdoblado en Maese Pedro que manipula las marionetas y el declarador que enuncia o muestra, con alguna irónica interrupción del propio don Quijote como puntilloso observador - que distancia críticamente la historia proclamada como verdadera; un constante frotamiento dialéctico de la realidad y la ficción (y de la práctica teatral y su teoría); y un espectador que, concernido por esa misma dialéctica, pasa de observador a agente de la acción. Porque, de repente, la historia atañe de

\footnotetext{
30 "Y aquel personaje que alli asoma con corona en la cabeza y ceptro en las manos es el emperador Carlomagno [...], el cual [...] le sale a reñir, y adviertan con la vehemencia y ahínco que le riñe, que no parece sino que le quiere dar con el ceptro media docena de coscorrones... [...] Miren vuestras mercedes también como el emperador vuelve las espaldas y deja despechado a don Gaiferos, el cual ya ven como arroja, impaciente de cólera, lejos de sí el tablero y las tablas [...] Vuelvan vuestras mercedes los ojos a aquella torre que alli aparece [...], y aquella dama que en el balcón aparece, vestida a lo moro, es la sin par Melisendra... [...] ¿No veen también a aquel moro que callandico y pasito a paso, puesto el dedo en la boca, se llega por las espaldas de Melisendra? Pues miren como le da un beso en mitad de los labios, y la priesa que ella se da a escupir, y a limpiárselos con la blanca manga de su camisa y como se lamenta y se arranca de pesar sus hermosos cabellos [...] basta ver cómo don Gaiferos se descubre, y que por los ademanes alegres que Melisendra hace se nos da a entender que ella lo ha conocido, y más ahora que vemos que se descuelga del balcón... [...] Veis también como los relinchos del caballo dan señales que va contento..." (II, 26)

${ }^{31}$ Apostilla pertinentemente el pretendido Maese Pedro: "Muchacho, no te metas en dibujos [...] Sigue tu canto Ilano, y no te metas en contrapuntos, que se suelen quebrar de sotiles..."

32 "Cervantes y el teatro del Quijote", Hispania, 88 (2005), pp. 45-46.
} 
nuevo a don Quijote. Desea elevar las figuras desde su condición guiñolesca al estatuto de ethos literario y artístico que impele a la acción. El hidalgo, desenvainando la espada, acomete el retablo "y con acelerada y nunca vista furia comenzó a llover cuchilladas sobre la titerera morisma, derribando a unos, descabezando a otros, estropeando a éste, destrozando a aquél..." (II, 26). Los mandoblazos acaban con todas las jarcias (aparejos) y figuras de la mercadería guiñolesca de Maese Pedro:

Deténgase vuesa merced, señor don Quijote, y advierta que estos que derriba, destroza y mata no son verdaderos moros, sino unas figurillas de pasta." (II, 26)

El hidalgo, que ha buscado insistentemente su papel en el retablo, cifra su entrada en escena en un cataclismo iconoclasta desde el que incorporar una vez más, aunque sea de manera sobreactuada, la figura heroica del caballero que tanto le ha costado componer. ${ }^{33} \mathrm{El}$ ojitapado Ginés de Pasamonte concluye compungido: "En fin, el Caballero de la Triste Figura había de ser aquel que había de desfigurar las mías" (II, 26). Aunque a don Quijote le cueste su furia destrozatíteres unos buenos 43 reales "por las muchas destrozadas figuras" (II, 26), su negra honrilla esta reparada. Como cuando Sancho, capítulos después, reivindica a su propio amo delante de lo Duques: "De los Leones ha de decir vuestra alteza, que ya no hay triste figura ni figuro." (II, 30)

El episodio del retablo fue interpretado iconográficamente, entre otros, en el grabado de François Poilly, el joven, a partir de la excelente pintura de Charles-Antoine Coypel (Don Quijote acuchilla a los titeres de Maese Pedro) [Fig. 4] reflejando, dentro del resabio cortesano y pintoresquista de éste, el momento culminante del desbaratamiento del teatro de marionetas por parte del caballero que centra la perspectiva de la composición. Tanto en este grabado como en del Anker Smith (a partir del dibujo de Robert Smirke para la edición inglesa de 1818) la composición reproduce con exactitud el juego del "teatro dentro del teatro" -aunque interpreta muy libremente el artilugio titeril-: los espectadores miran al caballero que, en el frenesí de su actuación, se incrusta literalmente en el retablo (insinuado mediante amplios cortinajes, con Maese Pedro controlando los hilos de los títeres). La imagen de Maese Pedro, que Coypel había estilizado con vestimenta morisca, aquí es más fiel, mostrando el parche en el ojo. Mucho más toscos, pero siguiendo la misma línea compositiva, son el grabado anónimo de la edición inglesa de 1687 [Fig. 5] y la xilografía de Tony Johanson en una edición francesa de 1836. La cromolitografia de Gottfriend Franz, en la edición de 1882, con formas y colores muy limpios empieza a sugerir un estilo efectista de cómic. Por el contrario, el dibujo de Gustavo Doré (grabado por Henri Pisan) de 1863 [Fig. 6], polariza toda la energía de la representación en el hecho mismo de la historia contada en el retablo: los protagonistas pasan a ser las propias marionetas con cuatro manos que sostienen sus hilos desde lo alto del teatrillo. Don Quijote permanece tenso y expectante (por algo el título es Don Quijote, Sancho y compañia ven la obra de Melisendra y Gaiferos en el retablo de titeres de Maese Pedro). Antonio Saura, en los dibujos que acompañaron a la edición de Martín de Riquer de 1987 [Fig. 7], da una particularísima visión, por supuesto nada figurativa, del episodio: interpreta el retablo en su

\footnotetext{
${ }^{33}$ El episodio, como ha señalado la crítica, puede estar alentado por el que incluye Avellaneda en su Quijote (caps. XXVI-XXVII), y en el cual don Quijote el Malo topa en una venta con unos cómicos que ensayan la obra de Lope El testimonio vengado. Don Quijote, al observar que nadie acude en defensa de la calumniada reina de Navarra, la emprende a cintarazos con los farsantes.
} 
sentido e iconografia más primaria: la historia que se cuenta en imágenes y que se inscribe en sucesivas tablas. La figuración abstracta de Saura impide la identificación concreta de la o las escenas, pero sí sabemos que el conjunto se refiere a un párrafo muy concreto citado por el propio artista, aquel en el que don Quijote reprende al joven declarador pidiéndole que "siga vuestra historia línea recta, y no os metáis en las curvas o transversales". Es como si Saura hubiera ordenado en un esfuerzo de abstracta síntesis la potente energía gestual que emana de los personajes (reales o titeres) sujetos al esquema del retablo. En la figura central, se intuye la presencia de don Quijote que, como dice Robert Girard, llevando el coeficiente de ilusión a la potencial superior, ${ }^{34}$ desenvaina su espada para perturbar el ordenado sistema de un espectáculo que no ha sabido contemplar con suficiente distancia estética y dentro del que precisa autoincluirse en clave (aquí sí) de realista destrucción redentora.

Erasmo había evocado en su Elogio de la locura a aquel hombre de la antigua Grecia

que había estado loco hasta el punto de ir todos los días a un teatro vacío donde él solo tomaba asiento, y allí reía, aplaudía y se divertía creyendo ver representar comedias admirables, lo cual no era obstáculo para que fuese muy cuerdo en todos los demás menesteres, alegre con los amigos, bondadoso con su mujer e indulgente con los criados... ${ }^{35}$

Pero aunque este texto se haya tomado tradicionalmente como bosquejo de la locura quijotesca entreverada de lúcidos intervalos, tendremos que reconocer que Cervantes, en realidad, hace de don Quijote no un espectador sino un actor, un ser actuante, en trance permanente de construir su figura. Por la misma razón el hidalgo pasa toda la obra destruyendo las figuras alternativas, las figuras grotescas que empañan el sueño artístico de su perfecta imitación grave de las imágenes y hechos librescos. Pero, en todo caso, esta imitación es siempre dramática y en peripecia, es decir, en acción inmersa en la realidad y, por lo tanto, expuesta y vulnerable. Don Quijote escapa del marco oscuro y saturnino de sus lecturas de biblioteca a la aventura libertaria, rompiendo así con el modelo de caballero cortesano que, como le dice significativamente a su ama

\begin{abstract}
sin salir de sus aposentos ni de los umbrales de la corte, se pasean por todo el mundo, mirando un mapa, sin costarles blanca, ni padecer calor ni frío, ni hambre ni sed; pero nosotros, los caballeros andantes verdaderos, al sol, al frío, al aire, a las inclemencias del cielo, de noche y de día, a pie y a caballo, medimos toda la tierra con nuestros mismos pies, y no solamente conocemos los enemigos pintados, sino en su mismo ser, y en todo trance y en toda ocasión los acometemos ... (II, 6)
\end{abstract}

La dignidad heroica de la imagen creada y gestionada en escena por don Quijote es saber que la vida pasa como sueño o teatro o improvisación pero que debe vivirse como si no lo fuese. Dicho de otro modo, elevándose sobre la gran tragedia de la modernidad: la profunda imposibilidad de la imitatio hasta sus últimas consecuencias y, por lo tanto, la ausencia del ideal en una realidad moderna desencantada. No sin razón, uno de los poemas que irónicamente inserta Cervantes en los preliminares de su obra para blindarla contra halagüeñas "autoridades" son las décimas en cabo roto de Urganda la Desconocida:

No indiscretos hieroglíficos

\footnotetext{
${ }^{34}$ R. Girard, Mentira romántica y verdad novelesca, Barcelona, Anagrama, 1985, p. 133.

${ }^{35}$ Citado por A. Vilanova, Erasmo y Cervantes, Barcelona, CSIC, 1949, pp. 49-50.
} 
estampes en el escudo, que, cuando es todo figuras, con ruines puntos se envida.

Todo es figuras. Sólo que Cervantes buscará obsesivamente la dignidad de la proteica materialización de éstas en la propia escritura. Lejos de la impropiedad desatinada de los libros de caballerías, a los que el canónigo de Toledo acusaba de hacer un cuerpo de fábula "que más parece llevan intención a formar una quimera o un monstruo que a hacer una figura proporcionada" (I, 47), Cervantes alimenta nuestro imaginario de la urgente necesidad de discernimiento crítico en la propia figura de su héroe siempre en incansable competencia con otras figuras. Opción ética que siempre se sustancia en la voluntad de ser y en la verdad comprometida con la conciencia de uno mismo; por eso, al comienzo de la segunda parte, instará a Sancho a que le cuente qué se opina de él en su lugar tras la primera entrega de sus peripecias, y que lo haga sin adulación, "en su ser y figura propia" (II, 2).

Será una forma luminosamente moderna de afirmar la identidad. En esa tensión heroica (que el romanticismo se encargó, incluso en sus manifestaciones plásticas, de convertir en tragedia agitada, poblada de fantasmas) quizá hemos juzgado la imagen del Caballero de la Triste Figura desde el ejercicio del liberalismo rentable - la terca moralización sobre el coste de la pérdida del sentido de la realidad puede incluirse en este punto de vista- y no desde la voluntad, gloriosamente gratuita, de la materialización de un ideal poético. Un ideal poético universal, pero que ha de vivirse fatalmente como experiencia individual, aunque sea a costa de caer derrotado en la playa de Barcino, allí donde el deber ser aristotélico se torna - ejemplar lección de belleza - en el es particular del ser humano. Quizá no fuera consciente de ello don Quijote, absorbido por su permanente obsesión de entrar en situación. Lo es Sancho (lo es, por tanto, Cervantes) cuando le dice a su amo:

Yo apostaré que antes de mucho tiempo no ha de haber bodegón, venta ni mesón, o tienda de barbero, donde no ande pintada la historia de nuestras hazañas..." (II, 71).

Volviendo a Ortega y Gasset, éste dijo también que lejos, sobre la llanada manchega, la larga figura de don Quijote se encorva como un signo de interrogación. Imagen que me da pie para sugerir el quiebro definitivo, el vuelco desde la imagen interesadamente realista, incluso idealizadamente realista, a la imagen abstracta, definitivamente desrealizada que la crítica y la plástica modernas han trazado respecto a nuestro clásico. Correspondió a Honoré Daumier (1808-1879) romper con la tradición excesivamente narrativa de las representaciones del hidalgo en su extensa serie de óleos y dibujos. Fue el primero en eliminar la anécdota ${ }^{36}$ y adensar su imagen en una mancha apenas sombreada, simplificada y expresiva. Era, en efecto, la puerta de una opción iconográfica moderna que, como intuye el texto de Ortega de 1914, va a contemporaneizar definitivamente la imagen del caballero a fuerza de sustraerle la impronta de una excesivo naturalismo retórico, casticista y patriótico, irremisible herencia, como es sabido, del ideario del 98. El urgente trazo de la silueta o figura quijotesca como signo de interrogación vendrá así estimulada por el hallazgo de la producción sobre papel de Daumier en 1850, pero secundada de manera más evidente por alguno de los dibujos realizados en tinta, líneas de obsesivos torbellinos, de

\footnotetext{
${ }^{36}$ J.L. Giménez Frontín, op. y loc. cit., pp. 15-16.
} 
Salvador Dalí (1904-1989) en $1945 ;^{37}$ o por el propio Pablo Picasso (1881-1973), especialmente el realizado en 1955, con motivo del trescientos cincuenta aniversario de la obra, que presenta a don Quijote sobre Rocinante convertido en una enérgica y estirada silueta de trazos de tinta china negra [Fig. 8$],{ }^{38}$ y que ha venido en convertirse en emblema de la moderna reproductibilidad del personaje en el imaginario popular. Sin embargo, el destilado final de esta imagen, en su sentido más trascendente, emotivo y casi metafísico corresponde a la mano de Antonio Saura (1930-1998), que somete al mito a una clave de mínima signicidad, casi grafológica [Fig. 9]. Don Quijote será menos aún que una mancha o un cúmulo de líneas de grueso trazado (como procede en algunos otros dibujos de la serie que realiza en 1987); es el gesto desnudo y medular trazado sobre el vacío en el que tocamos la fantasmal intuición orteguiana: la espalda encorvada en el alzado abstracto de don Quijote y esa largura estilizada de su cuerpo tendido al interrogante del futuro. Cabe seguir creyendo en la dignidad de esa figura a la que cada época parece esperar desde la lejanía y que se actualiza en permanente diálogo con quien lo lee, lo pinta o lo imagina. A fin de cuentas don Quijote, en la poliédrica libertad de la multiplicidad de figuras que emanan de la escritura de Cervantes, es, para cada uno de nosotros, una elección.

\footnotetext{
${ }^{37}$ Fueron realizados para la edición de la primera parte de la obra que se publicaria al año siguiente: The Life and Achievements of the Renowed Don Quixote de la Mancha (Nueva York, The Modern Library, Random House Inc., 1946).

${ }^{38}$ La critica ha subrayado la posible inspiración de Picasso para este dibujo en las esquematizadas siluetas de don Quijote y Sancho Panza en la pintura de su maestro de juventud Muñoz Degrain, Principio de la aventura de los molinos (ca. 1917), así como en la escultura de pequeño formato, en hierro forjado, Don Quijote de Julio González (realizada en torno a 1929-1930). La factura visual de ésta última remite con contundencia a la grafia del signo interrogativo.
} 


\section{ILUSTRACIONES}

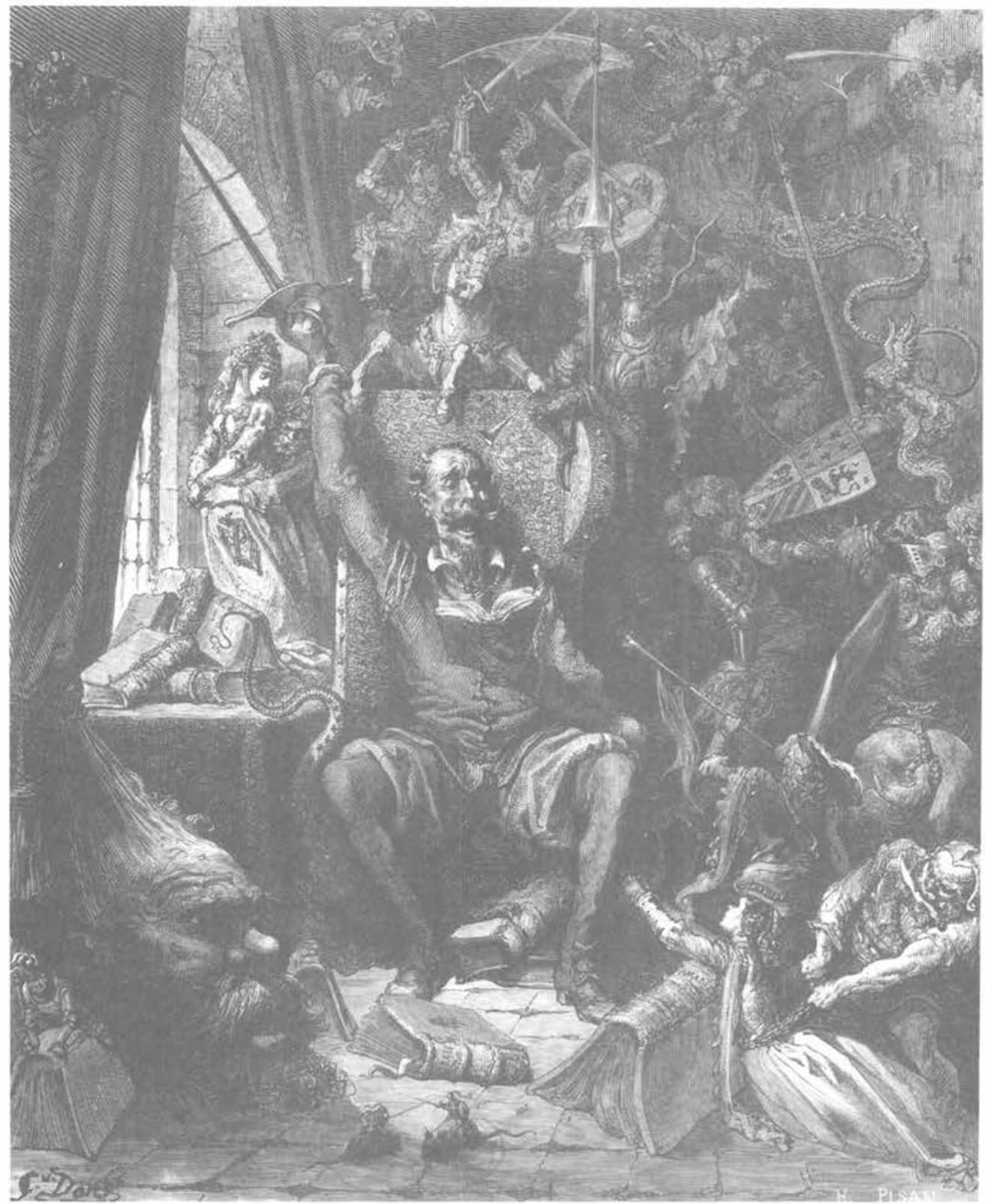

Fig. 1. Henri Pisan por dibujo de Gustavo Doré (1863): Don Quijote leyendo libros de caballería en su estudio (Q, I, 1). Xilografía. The Hispanic Society of America, N. York. 


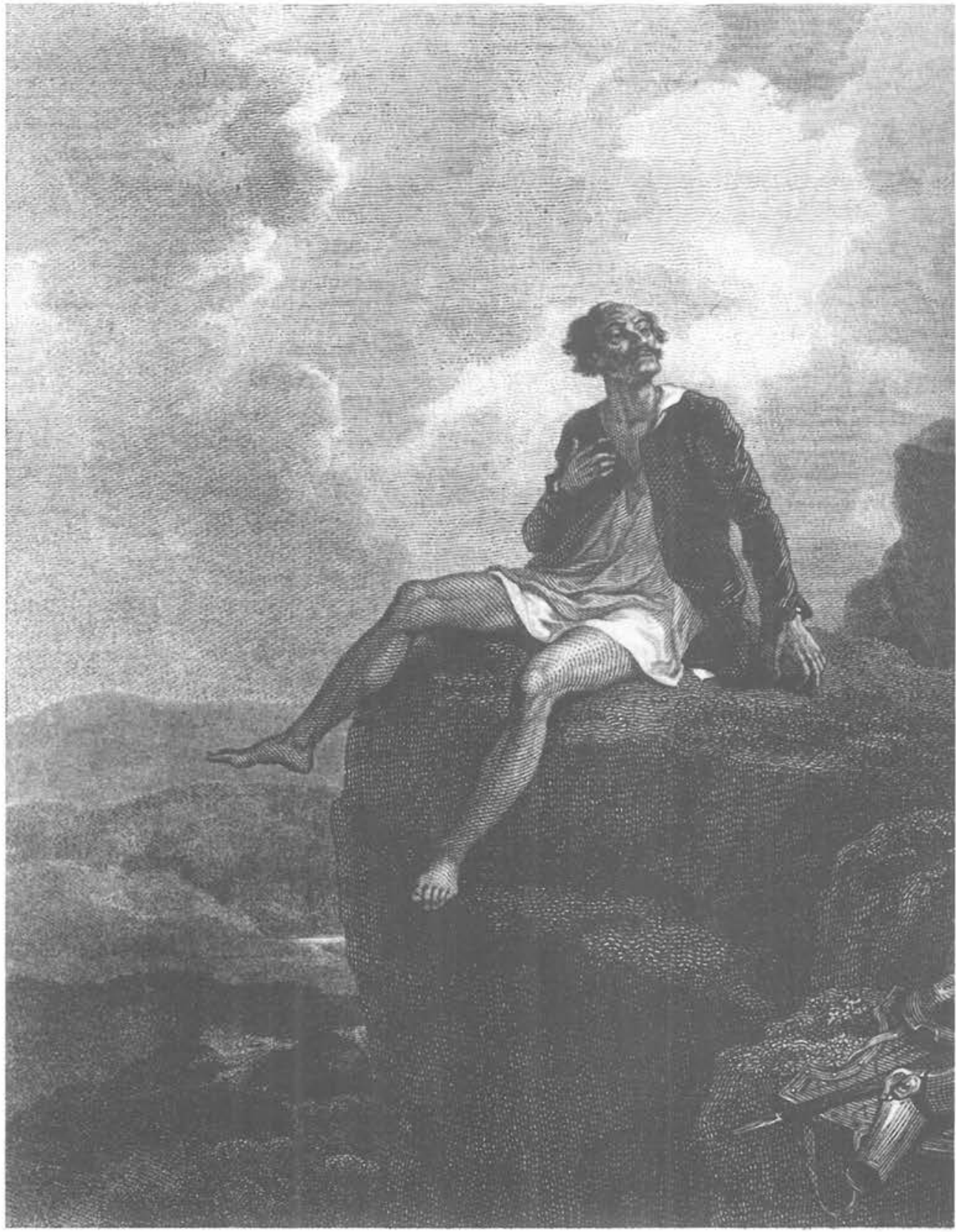

Fig. 2. Francis Engleheart por dibujo de Robert Smirke (1818): Penitencia de don Quijote en Sierra Morena $(\mathrm{Q}, \mathrm{I}, 25)$. Talla dulce. The Hispanic Society of America, N. York. 


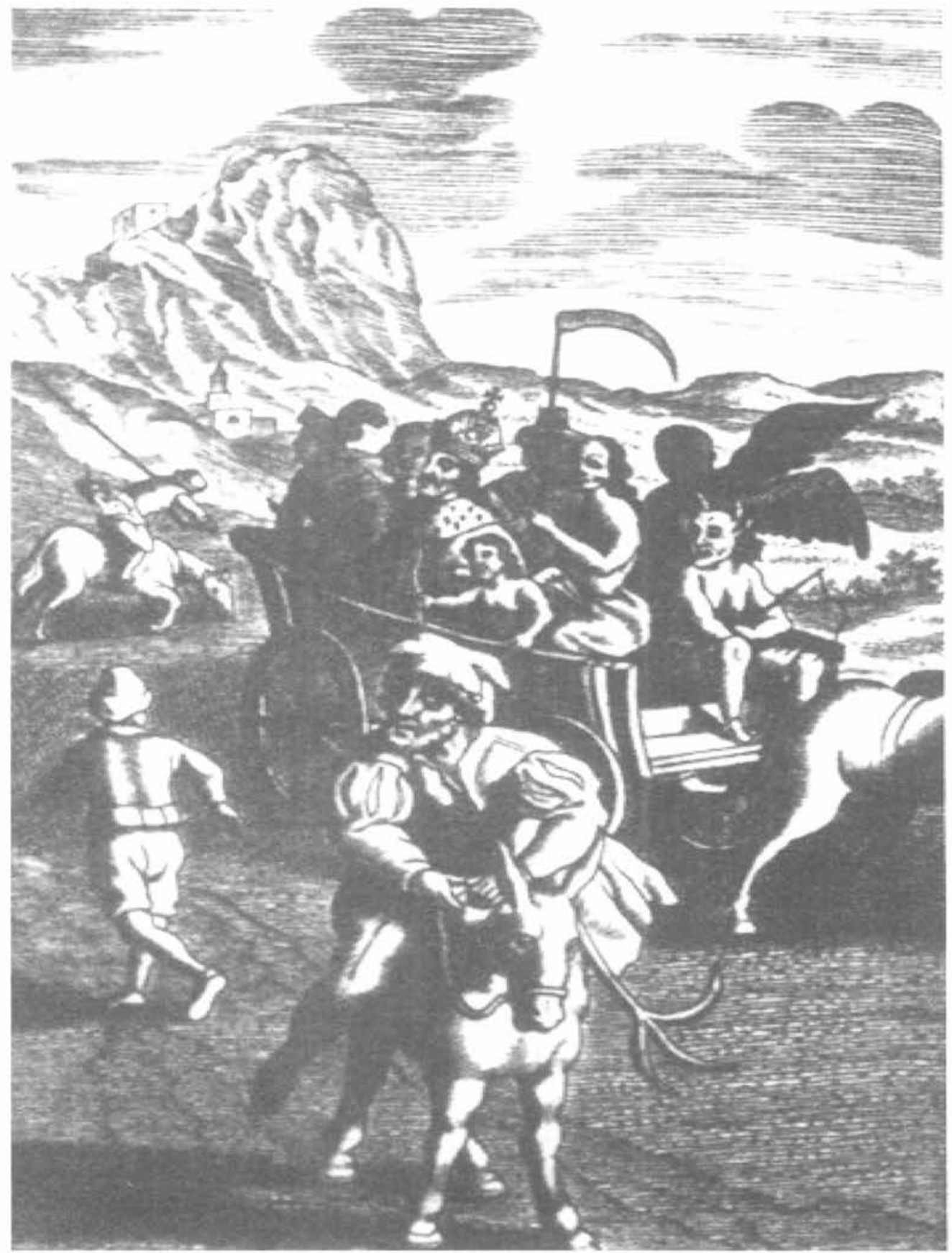

Fig. 3. Frederick Bouttas (1662): Don Quijote y las Carretas de la Muerte (Q, II, 11). 


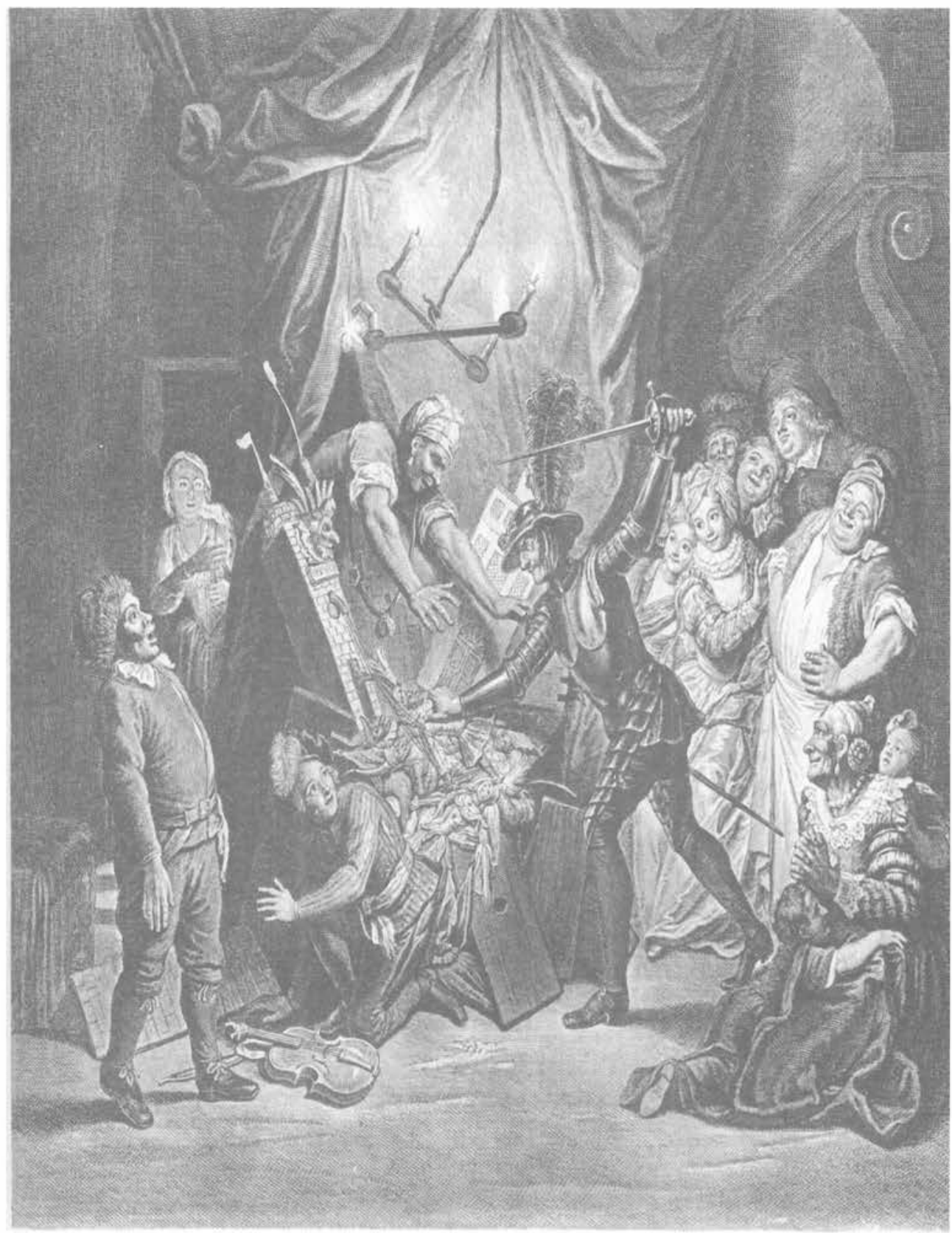

Fig. 4. François Poilly "El joven", por pintura de Charles-Antoine Coypel (ca. 723-1736): Don Quijote acuchilla a los títeres de Maese Pedro $(\mathrm{Q}, \mathrm{II}, 26)$. Talla dulce. The Hispanic Society of America, N. York. 


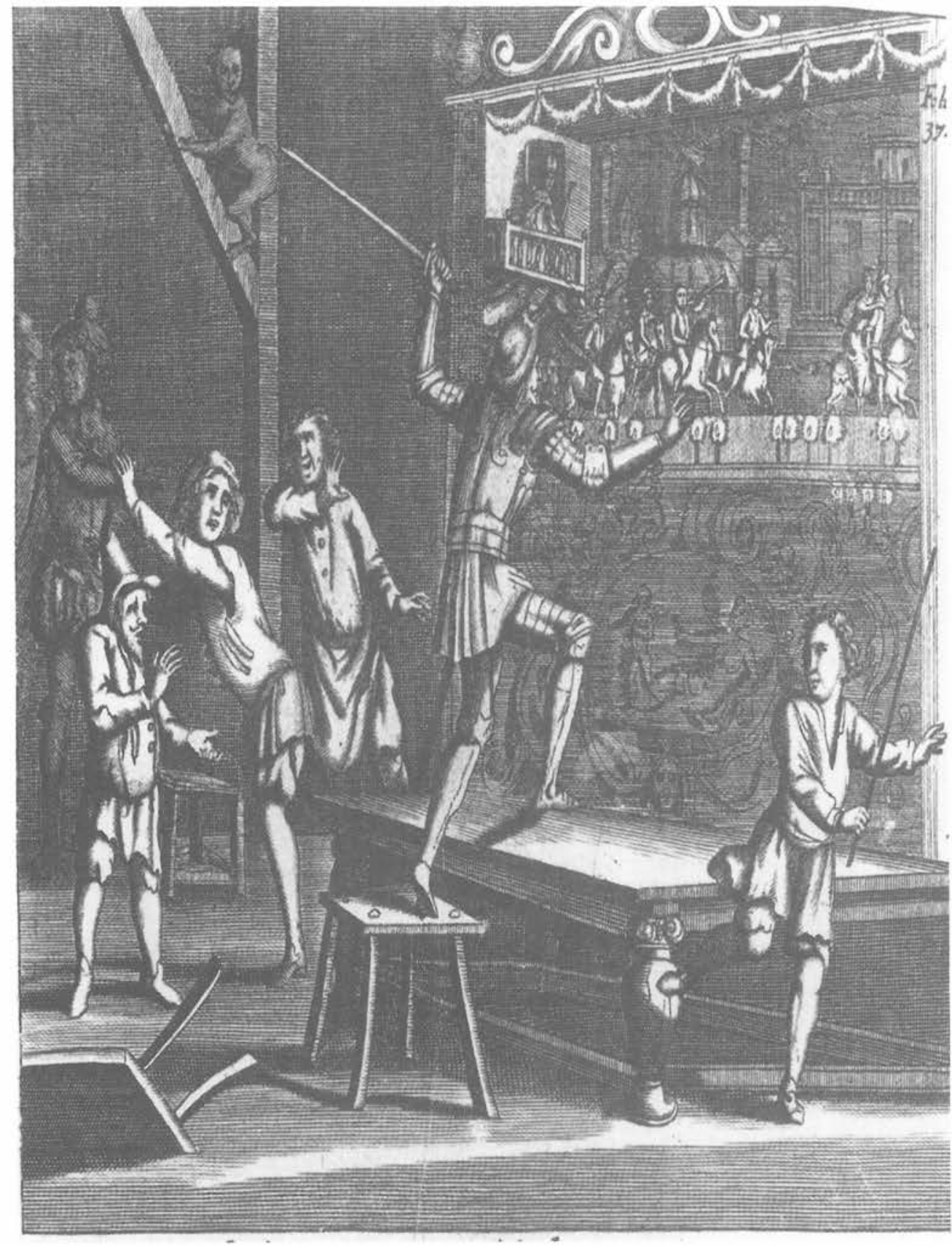

Fig. 5. Anónimo (1687): Encuentro con los títeres (Q, II, 26). Talla dulce. The Hispanic Society of America, N. York. 


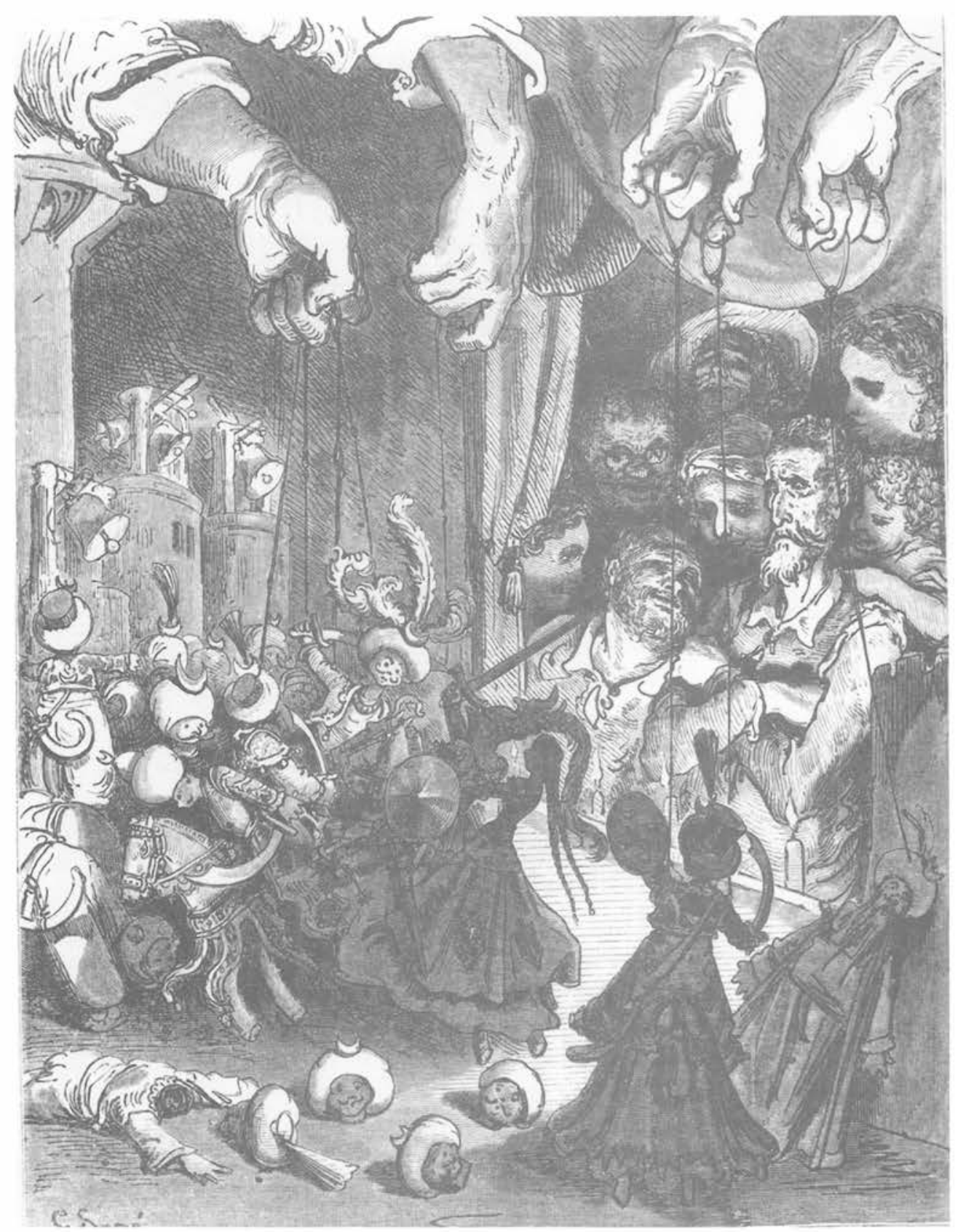

Fig. 6. Henri Pisan por dibujo de Gustavo Doré (1863): Don Quijote, Sancho y compañía ven la obra de Melisendra y don Gaiferos en el retablo de títeres de Maese Pedro (Q, II, 26). Xilografía. The Hispanic Society of America, N. York. 


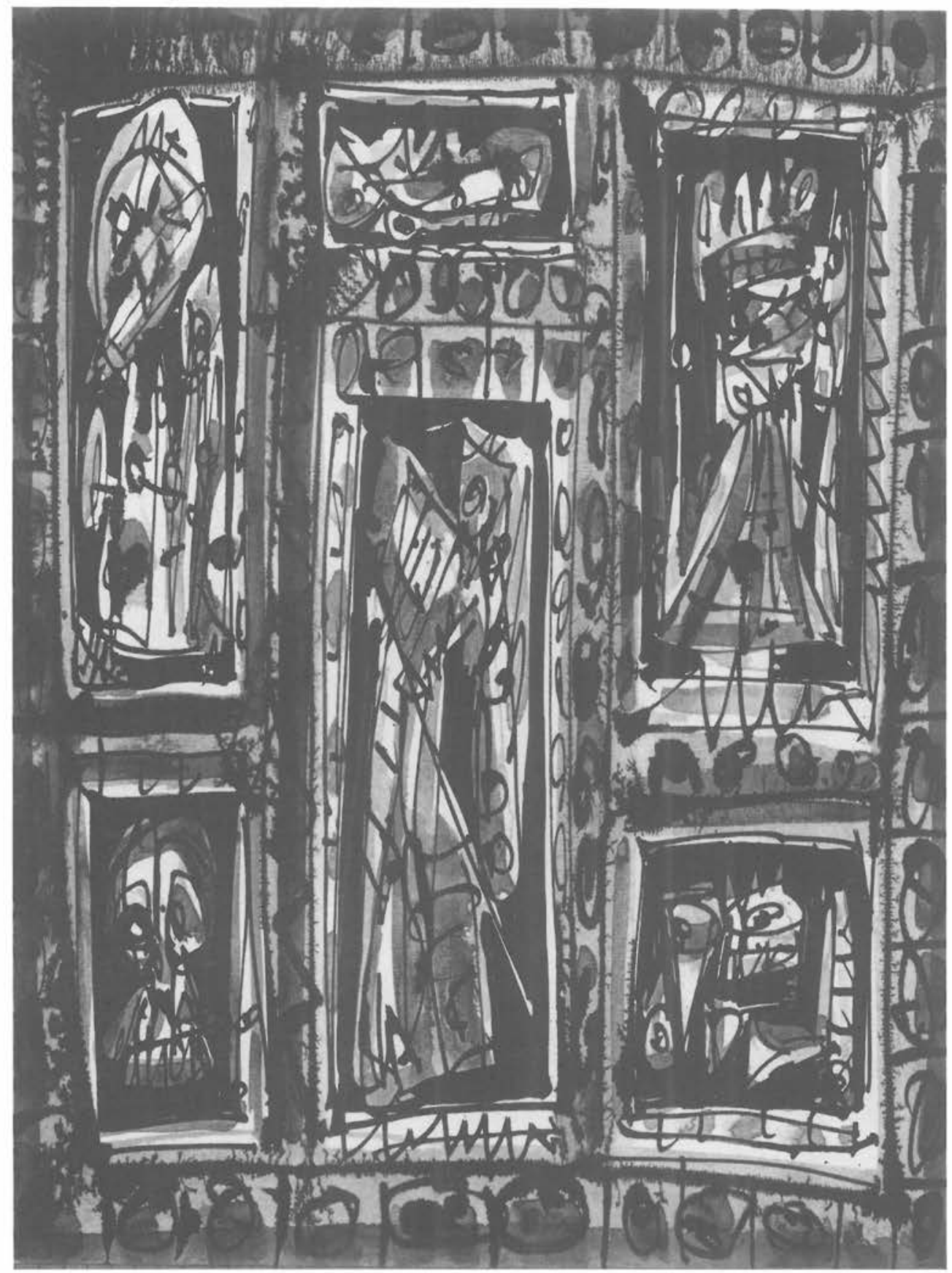

Fig. 7. Antonio Saura (1987): Retablo de Maese Pedro. Dibujo. Ed. de Martín de Riquer, 1987. 


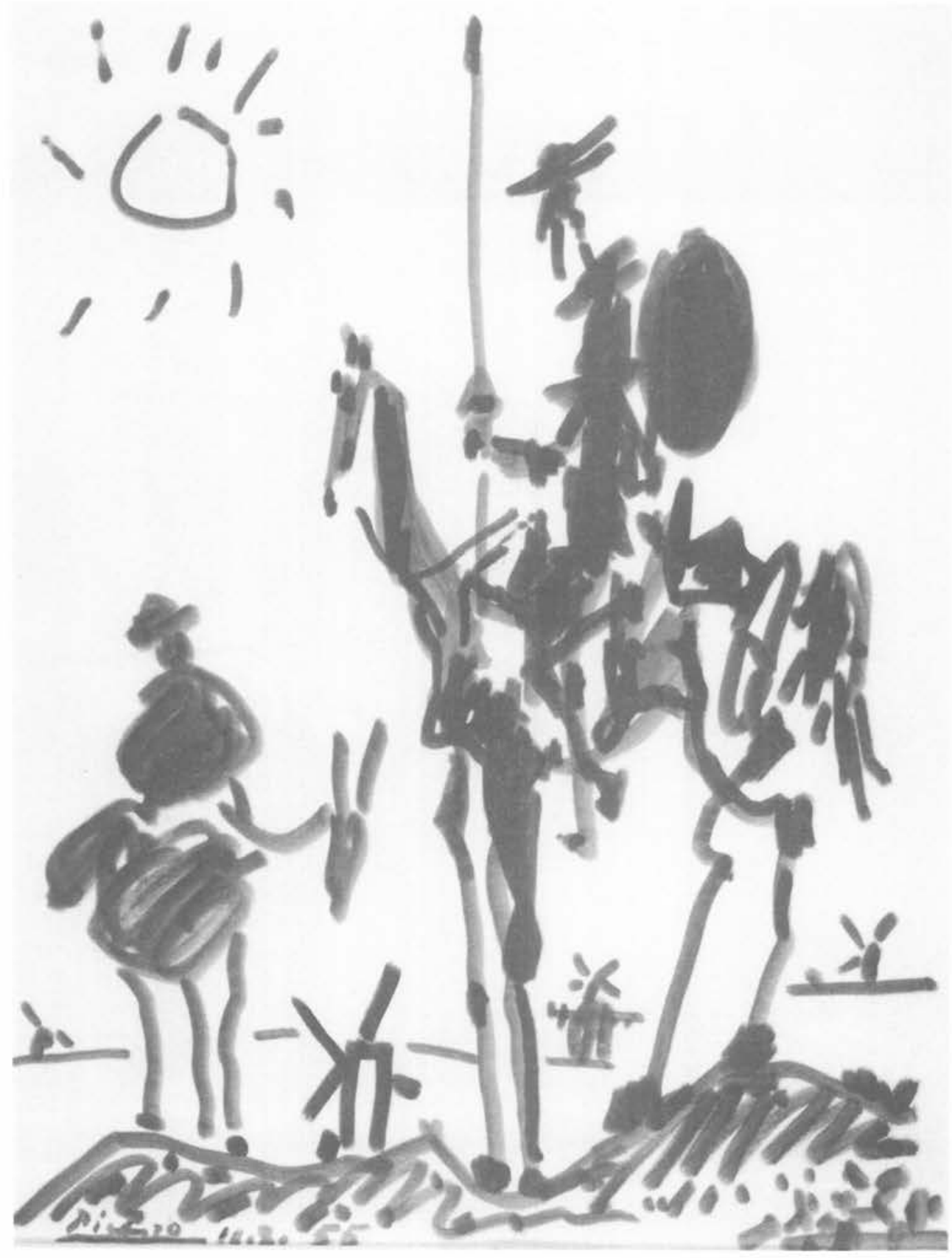

Fig. 8. Pablo Ruiz Picasso (1955): Don Quijote. Dibujo. Musée d'Art et d'Histoire, Saint-Denis. 
Don Quijote y sus figuras: de la imitación al retablo de Maese Pedro

195

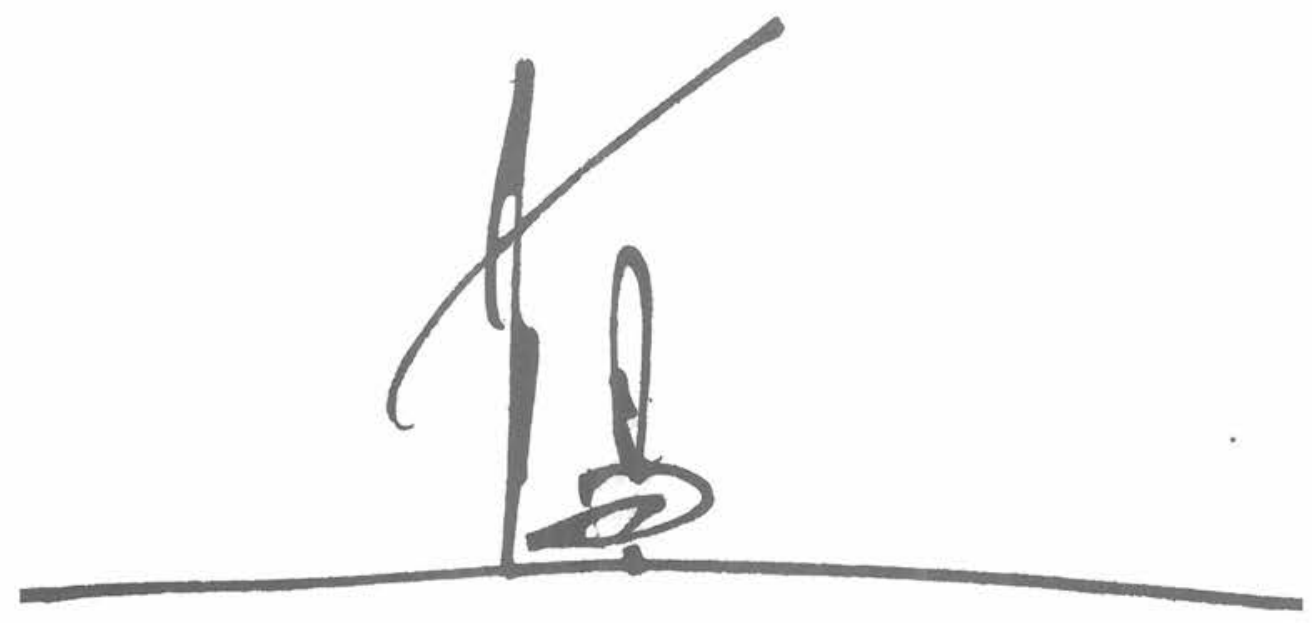

Fig. 9. Antonio Saura (1987): Don Quijote y Sancho Panza. Dibujo. Ed. de Martín de Riquer, 1987. 
